\title{
MIROSLAV HUBMAJER (1851-1910) \\ DANES POZABLJEN, SVOJE ČASE NAJSLAVNEJŠI SLOVENSKI \\ JUNAK
}

\section{BOŽIDAR JEZERNIK}

Nevesinjska puška je 9. julija 1875 napovedala začetek oborožene vstaje v Hercegovini. Začelo se je kot kmečki protest, a se razvilo v hercegovski upor in zgodovinski dogodek vjugozahodni Evropi. Odprto je bilo t. i. vzhodno vprašanje, ki je sprožilo veliko zanimanje evropskih novinarjev, politikov in javnosti, še posebej slovanski prebivalci iz sosednjih držav so z zanimanjem spremljali razvoj. Eden prvih, ki se je odzval pozivu Matere Slave, je bil Friedrich Hubmayer, mladi slovenski nacionalist iz Ljubljane. Kljub svojemu velikemu slovesu $v$ drugi polovici 19. stoletja je skoraj popolnoma pozabljen.

Ključne besede: Miroslav Hubmajer, Nevesinjska puška, vzhodno vprašanje, Petar Mrkonjić (Petar Karadordević), slovanski nacionalizem
The Nevesinje Uprising (SCr. Nevesinjska puška, literally 'Nevesinje Rifle') marked the beginning of the armed insurgency in Herzegovina on July 9th, 1875. Starting as a peasant revolt, the Herzegovinian insurgency developed into a historical event of seismic importance. It opened the Eastern Question and attracted huge interest among European journalists, politicians, and the public, and especially the Slavic population in neighboring countries followed the developments with keen interest. One of the first to respond to this Slavic cause was Friedrich Hubmayer (later Miroslav Hubmajer), a young Slovenian nationalist from Ljubljana. However, despite his great reputation in the second half of the nineteenth century, Hubmajer is almost completely forgotten today.

Keywords: Miroslav Hubmajer, Nevesinje Uprising, Oriental Question, Peter Mrkonjić (Peter Karadordević), Slavic nationalism

V drugi polovici 19. stoletja so se na Balkanskem polotoku razmere za krščansko prebivalstvo močno poslabšale. Visoka Porta je bila predaleč od obmejnih provinc in se je srečevala s hudimi težavami pri uveljavljanju pravnih reform, ki so spreminjale položaj lokalne aristokracije. Za povrh je modernizacija države z uvajanjem denarnega gospodarstva, kolikor je dosegla te province, le še povečevala obremenitve raje, na kateri je v celoti slonelo davčno breme. Za rajo, ki je le stežka prišla do denarja, je bilo še posebej neugodno izterjevanje davkov v denarju namesto v naravi. ${ }^{1}$ Slaba letina leta 1873 v Anatoliji, ki so ji sledile huda zima in poplave, je povečala pritisk na province na jugovzhodu Evrope. Pobiranje davkov prek zakupnikov je razmere še dodatno poslabšalo. Ko so v začetku julija 1875 kljub slabi letini v Hercegovini tamkajšnji pobiralci davkov s silo izterjevali visoke davke, je to zanetilo oboroženo vstajo (Mandić 1910: 7; Stojanović 1939: 15; Pavlowitch 1999: 108).

Davčni zakupniki so davke izterjevali neprizanesljivo. Širile so se vesti, da so morali plačevati po 20 krajcarjev na glavo tudi tisti, ki niso ničesar imeli in pridelali; davek so morali plačevati še tisti, ki niso imeli drugega kot deset prstov na rokah. Tako je veleval

1 Gl. npr. M. D., Što daje raja u Turskoj caru i agama kao godišnji danak. Glas Crnogoraca, 15. 1. 1876: 3. 
uradni ukaz, a izterjevalci so ravnali še vse huje, in gorje tistim, ki niso plačali. Zaradi tega je krščansko prebivalstvo pobegnilo na ozemlje Avstro-Ogrske; do meseca septembra 1875 je bilo že čez 100.000 takih, ki niso bili sposobni za bojevanje, v Slavoniji, Dalmaciji in na Hrvaškem, v Črni gori pa okoli 30.000. Za orožje sposobni so se zbrali v čete; nosili so avstrijske zastave in klicali »našemu kralju Francu Jožefu I«. Oboroženi s tem, kar je kdo imel, sekiro, motiko, puško ali handžarjem, so se zarotili: „Svoboda ali smrt, pod dušmanina pa ne nazaj. Boj do zadnje kapljice krvi!« (Aléšovec 1878: 16-17).

Pretežko davčno breme, naloženo krščanski raji, pa je bilo samo povod za vstajo. Vzrok je bila tuja propaganda za splošno vstajo krščanskega prebivalstva v Osmanskem cesarstvu (Suavi 1875: 2; De Worms 1877: 62-63). To oceno potrjujeta tudi sodobni angleški popotnici Georgina Mackenzie in Paulina Irby, ki sta pravi vzrok videli v prebujenju srbske narodne zavesti, zaradi česar so bili Srbi sredi druge polovice 19. stoletja trdno odločeni, da odvržejo tuji "turški« jarem (Mackenzie in Irby 1877: 15). Enako je menil tudi Jakob Aléšovec, ki je položaj opisal z bolj ljudskim jezikom takole: »Turek hoče na vsak način biti gospodar kristjana, ki mu je pes, kristjan pa ni hotel več pes biti, ampak človek, ${ }^{2}$ in tako je ostalo vse v orožji« (Aléšovec 1878: 24).

Nevesinjska puška je začetek oborožene vstaje naznanila 9. julija 1875. Iz Nevesinja se je vstaja hitro razširila po vsej Hercegovini, čeprav brez osrednje organizacije. Hercegovci so živeli pastirsko življenje in redno gnali svoje črede na pašo v planine, kjer so si znali najti zavetišče in preživeti z več mesa kot kruha. Iz planinskih postojank so v času vstaje gverilsko napadali osmanske vojaške enote, vasi z muslimanskim prebivalstvom in trgovce. $\mathrm{V}$ prvih dveh mesecih se jim je posrečilo osamiti vojaške posadke v Hercegovini, uničiti komunikacije in poraziti osmanske okrepitve, poslane iz drugih delov cesarstva. Konec meseca avgusta je vstaja zajela še Bosno, zlasti na ozemlju vzdolž meje z Avstro-Ogrsko. Za razliko od vstaje v Hercegovini, kjer so se uprli tako pravoslavni kot katoliki, je ta v Bosni ostala omejena na pravoslavno prebivalstvo; muslimanski predeli srednje in severovzhodne Bosne so ostali lojalni sultanu (Pavlowitch 1999: 108-109).

Zaradi notranjih slabosti in osmanske vojaške premoči kakor tudi diplomatske igre velesil je vstaja, omejena izključno na srbski del prebivalstva in brez opore med muslimanskim in hrvaškim prebivalstvom, doživela poraz. Med vstajo je bilo namreč izgubilo življenje kakih 150.000 oseb, medtem ko je kakih 200.000 neoboroženih civilistov prebegnilo na ozemlje dvojne monarhije (Pavlović 2004: 80). Vstaja ni terjala le visokega davka v krvi, temveč je povzročila tudi ogromno škode v infrastrukturi. Vasi širom Hercegovine so v zelo kratkem času opustele, številne hiše so bile požgane. ${ }^{3}$

2 Vasa Pelagić je v delu Pokuśaji za narodno i lično unapređenje tistim, ki so obsojali njegovo "pretirano" delovanje, pojasnil, da je tako ravnal predvsem z namenom, da bi pokazal „tiraniji, da mi nismo več živali za jarem, ampak da smo narod ...« (nav. po Besarović 1947: 11).

3 Do ovoga časa. Glas Crnogoraca, , 6. 9. 1875: 1. - Vsi viri, navedeni zgolj z naslovom in mestom objave, so nepodpisani. 
Sodobna evropska središča diplomatske moči, zainteresirana za ohranjanje statusa quo na Balkanskem polotoku, so hotela ostati gluha in slepa za vesti iz Hercegovine in Bosne, a je tamkajšnja vstaja - tragični bilanci navkljub - temeljito pretresla takratni red v Evropi. Goriški Glas je prelomen pomen vstaje v obmejnih delih Osmanskega cesarstva že poleti 1875 opisal kratko in jedrnato: "Hercegovina in Bosna - to je zdaj središče vsega sveta«. ${ }^{4}$ Vstaja je namreč z vso brutalnostjo odprla t. i. vzhodno vprašanje. Sodobni britanski konservativni politik Henry de Worms ga je pojasnil v širšem pomenu kot vprašanje, ali je mogoče ohraniti osmansko navzočnost na jugovzhodu Evrope; če pa ni mogoče, kdo naj vlada na ozemlju, ki je bilo tedaj še pod sultanovo oblastjo? V ožjem pomenu pa se je omejevalo na prizadevanja, da bi Rusiji preprečili, da zasede to ozemlje zase (De Worms 1877: 5). Rivalstvo velikih sil za prestiž je dalo vstaji v Hercegovini in Bosni pomen, ki je daleč presegal njune meje. Vse skupaj je še dodatno zapletalo dejstvo, da Hercegovina in Bosna nista bili obdani s sorodnim prebivalstvom le z ene ali dveh, temveč z vseh štirih strani. V Hercegovino in Bosno je najrazličnejša pomoč vstajnikov pritekala z vseh strani. $Z$ vstajo pa so se od samega začetka prepletali tudi interesi vseh vpletenih strani, zato je njen pomen močno presegel težo in pomen, ki ga je imela sama po sebi. Ni sicer razvnela upora po vsem balkanskem delu Osmanskega cesarstva, je pa toliko bolj vnela srca in ume po vsem slovanskem svetu, kar ji je po eni strani dajalo moč, po drugi pa je bilo glavni vir njene šibkosti (Stojanović 1939: 16). Tedaj je bilo moč prvič zaznati balkanski "sod smodnika", ki je sprožil podiranje domin in je v sosledju vzrokov in posledic bistveno prispeval k podobi sveta, kakršno poznamo danes.

Vstaja je sprva pritegnila le malo pozornosti svetovne javnosti. Pariški Le Figaro je npr. 20. avgusta 1875 zapisal, kako je v zvezi z vstajo Parižane zanimalo predvsem vprašanje, kaj sploh pomeni ime 'Herzegovina': Ali je to ime baletne plesalke v Operi ali nov model klavirja, ki ga je izumil Herz?5

Če prva poročila o vstaji niso zbudila velikega zanimanja evropskih oblikovalcev javnega mnenja, se je to kmalu spremenilo. Avstro-ogrsko, rusko, britansko in francosko časopisje je kmalu vsak dan prinašalo bolj ali manj podrobna poročila o poteku vstaje, največje časopisne hiše so na vstajniško področje pošiljale posebne dopisnike. Njihova poročila o vstaji in razmerah v upornih deželah in njenih akterjih so približala dogajanje ne le bralcem po sosednjih in bližnjih državah, z dogajanjem so bili dobro seznanjeni bralci po vsej celini, dogajanje pa so dokaj redno spremljali tudi največji dnevniki v New Yorku in Chicagu.

Nemško in madžarsko časopisje v dvojni monarhiji sicer ni imelo takih težav z osnovnimi pojmi, je pa do dogajanja kazalo poudarjeno nevtralno stališče in vstaji ni pripisovalo zgodovinskega pomena. Tako so, na primer, poročali, da vstaja sploh ni bila vstaja, pač pa "vstaja», ali, še natančneje, "puč kmetov, ki se izmikajo plačevanju davka». ${ }^{6}$ Opazne

\footnotetext{
Zunanje države. Glas, 3. 9. 1875: 2-3.

5 Le Deux Ajax. Le Figaro, 20. 8. 1875: 1.

6 Politische Uebersicht. Laibacher Zeitung, 22. 8. 1875: 1226.
} 
težave so imeli tudi, ko je bilo treba najti kako lepo besedo za hercegovske ustaše, saj so hercegovske ustaše predstavljali kot primitivne ljudi brez smisla za kulturo. V tem duhu je nekaj dni po izbruhu vstaje provladni dnevnik Neue Freie Presse objavil novico, da so ustaši razvili avstrijsko zastavo. Uvodničar je novico pospremil z ironičnim komentarjem, da si sam niti ne želi takih sodržavljanov, »ki nosijo srajco prek čakšir in si nos usekavajo v roke«. ${ }^{7}$ Vstajnikom še bolj nenaklonjen je bil Laibacher Tagblatt. Njegovi bralci so lahko nekaj mesecev po začetku vstaje prebrali, da je ta pokazala zgolj "najgrše plati človeškega karakterja», to je "surovost in divjaštvo" tamkajšnjih prebivalcev. ${ }^{8}$

\section{PREBUJENJE MITSKIH KRALJEV}

Sosednji srbski kneževini, Srbija in Črna gora, sta vstajo krščanske raje v Hercegovini in Bosni ves čas izdatno podpirali z orožjem in strelivom, tudi s številnimi prostovoljci. Svoje ravnanje sta opravičevali s tem, da vojaško pomagata vstajnikom, da bi »osvobodili svoje brate«, čeprav sta bila dejanska motiva težnja, da bi razširili svoje ozemlje in utrdili svojo, tedaj še negotovo samostojnost (Mandić 1910: 10). Ob izbruhu vstaje v Hercegovini sta si knez Milan in knez Nikola razdelila interesni območji: prvi je želel Bosno, drugi Hercegovino (Milutinović 1953: 59). Tako Srbija kot Črna gora, posebno njeni dinastiji Obrenovićev in Petrovićev, pa tudi dinastija vizgnanstvu - Karađorđevići, so prihiteli med vstajnike in jim obljubljali svojo pomoč, če bodo za svojega poglavarja postavili njihovega kandidata in če bodo njihove čete med jurišanjem vzklikale ime tega in ne drugega kneza.

A potek vstaje je med obema srbskima kneževinama povzročil hudo rivalstvo. V Srbiji je prevladalo stališče, da bi priključitev Hercegovine k Črni gori spodbudila črnogorski separatizem, ker bi taka razširitev Črne gore lahko okrepila njeno rivalstvo s Srbijo. Knez Nikola si je prizadeval zatreti vpliv Srbije v Hercegovini, po drugi strani pa pridobiti na svojo stran hercegovske prvake in izobražence, da bi delovali za interese Črne gore. Z nezaupanjem je gledal na vse, ki so vzdrževali stike z Beogradom, celo prostovoljce, ki so prihajali v Hercegovino iz Srbije, je menda sumničil, da so delovali za priključitev Hercegovine $\mathrm{k}$ Srbiji (Aleksić 2016: 236-237). Še posebej oster trn v peti mu je bil Mićo Ljubibratić, zaupnik srbske vlade (Vukčević 1950: 115, 130; Vego 1953: 27; Ekmečić 1973: 147) oziroma - po opisu polkovnika v pruski vojski Wilhelma Rüstowa - "pansrbski agitator, v nekem smislu srbski Mazzini« (Rüstow 1877: 103).

Ljubibratić je po nagovoru srbske vlade več let delal za pripravo vstaje v Hercegovini. Ves čas ga je obiskoval predstavnik srbske vlade in ga spodbujal, naj prevzame tudi vodstvo bosanske vstaje. Srbska vlada mu je podelila naslov vojvoda in pravico, da je imenoval oficirje (Ekmečić 1973: 147). Njegov prihod v Hercegovino je vznemiril črnogorsko stran.

Seit vierzehn Tagen. Neue Freie Presse, 23. 7. 1875: 1.

8 Zur südslavischen Wechselseitigkeit. Laibacher Tagblatt, 5. 10. 1875: 1-2. 
Razlagali so ga namreč kot poskus, da bi vstajo podredili Srbiji in omejili črnogorske aspiracije na ozemlje vstajnikov (Aleksić 2016: 238). Zato črnogorski knez ni mogel križem rok opazovati, kaj dela »hercegovski Śćepan Mali« (Kos 2006: 67). V Hercegovino je poslal vojvodo Peka Pavlovića in mu naložil, naj onemogoči Ljubibratićeve namere. Stari borec proti »Turkom» je to storil in modo suo. Ljubibratiću je postavil zasedo in ga pretepel, mu pobral orožje, denar in osebne predmete ter ga prek meje prepeljal v Dubrovnik z rokami, zvezanimi na hrbtu (Stillman 1901 II: 111-112; 1932: 16; Ekmečić 1973: 147; Buha 2003: 189-190, 195).

Po črnogorskem prevzemu nadzora nad vstajniškim gibanjem v Hercegovini je vojvoda Ljubibratič moral zapustiti Hercegovino (Stillman 1932: 46). Na poti v Bosno so ga s četo soborcev v bližini Imotskega 11. marca 1876 zajele avstro-ogrske oblasti. Francoski popotnik Charles Yriarte se ni mogel načuditi avstro-ogrskim oblastem, da so po tolikšni uvidevnosti, kakršno so do tedaj kazale do ustašev, ki so mogli dnevno neovirano prihajati v Dalmacijo in se od tam poljubno vračati na prizorišča vstaje, nenadoma tako močno zavedale svoje nevtralnosti, da se niso potrudile preveriti niti tega, ali je bila vas Vinjani, kjer je so aretirali Ljubibratića, na ozemlju Dalmacije ali Osmanskega cesarstva (Yriarte 1981: 144). Srbska vlada ni sprejela ponudbe, da bi ga internirala v Srbiji (Prelog B. n. 1.: 121; Ekmečić 1973: 147), zato so ga odpeljali v Linz in ga tako povsem umaknili iz vstaje (Aleksić 2016: 238). Na pot v Linzu, konec meseca marca 1876, so Ljubibratića vodili skoz Sinj, Split, Šibenik, Zadar in Trst. Po vseh teh mestih so ga množice slovanskega prebivalstva pozdravljale $\mathrm{z}$ mahanjem $\mathrm{z}$ zastavami in $s$ prepevanjem patriotskih pesmi (Rüstow 1877: 133; Koetschet 1905: 38, 40-41; Gjurgjević 1910: 96; Novak 1925: 122-123). Tržaški Slovenci so mu tedaj izročili s srebrom okovan lovorjev venec z napisom: "Narodnemu heroju in slavnemu borcu za svobodo, Vojvodi M. Ljubibratiću« (Ljubibratić in Kruševac 1958: 275). ${ }^{9}$

Svoje načrte z vstajo v Hercegovini in Bosni so imeli tudi nekateri člani Glavnega odbora v Zagrebu, ki so zagovarjali stališče, da je Bosna hrvaška dežela (Slipičević idr. 1952: 127). Če so radikalni Srbi prek vstaje v Bosni želeli doseči obnovo Dušanovega cesarstva, so starčevićevski Hrvati upali na vstajenje Velike Hrvaške (Biankini 1925: 12-13). Hrepenenje po obnovi slavne preteklosti v podobi Velike Srbije oziroma Velike Hrvaške je doseglo tolikšno razsežnost, da so glavni akterji dogajanja v neposredni soseščini Bosne in Hercegovine postali tekmeci, ki so si prizadevali le za uresničitev vsak svojega cilja. Zato je nepodpisani pisec v Slovenskem Narodu, najverjetneje Miroslav Hubmajer, obsojal stališče ogrskih Srbov do vstaje, češ, da oni »Hercegovcem skoro ne privoščijo oslobojenja od Turka, ako bi morda prišli pod Hrvate in ne pod Srbijo«. To je bil po piščevem mnenju "grd egoizem, grdo bratosovraštvo, katerega se mora Srbstvo otresti in iznebiti, sicer ne bode druzega, nego narodna smrt na jugu za vse«. Pisec se je kritično obregnil tudi ob hrvaški

9 Po letu dni internacije se je vrnil v Srbijo, kjer je postal načelnik nekega mesta v pirotskem okrožju (Prelog B. n. 1.: 121). 
Obzor, ki naj bi z zadovoljstvom ponatiskoval »vse budalosti nevažnih srbskih listov, kakor je mali mladi 'Graničar,' ki od denes do jutri živi«, in s tem med Hrvati širil »mrzenje do Srbov, katerih je kljub vsemu več, kot je Hrvatov in nas skupaj«. ${ }^{10}$

Številni Hrvati so vstajo podpirali vse dotlej, dokler bosanski vstajniki niso 2. julija 1876 izdali Proglasa naroda bosanskoga o brezpogojni priključitvi »srbske« dežele Bosne h kneževini Srbiji (Besarović 1969: 106-107). Tedaj je prišlo do preobrata v srbsko-hrvaških odnosih - Hrvati so "postali odkriti nasprotniki« srbske stvari in »hladni do bosanske vstaje«. V zagrebškem tisku se je pojavila izjava hrvaške akademske mladine o hrvaški Bosni, »dragulju iz krone hrvaškega kralja Zvonimirja«; Srbi v izjavi niso bili niti omenjeni (Rüffner 1877: 292; Pelagić 1880: 85). Vasa Pelagić je v zvezi s tem ocenil, da je hrvaška inteligenca $s$ tem storila veliko napako, ker je "ponižala znanost, ki uči, da se ne klanjajo kroni Zvonimira, kakor madžarski dijaki Štefanovi kroni in sultanovi roki, pač pa pravičnosti in svobodi, resnici, enakosti in človečanskemu bratstvu“ (Pelagić 1880: 86). Vsiljevanje hrvaškega imena vstajnikom je bilo po Pelagiću, toliko bolj neprimerno, ker je bilo blizu 200.000 beguncev iz Bosne in Hercegovine, izmed katerih se ni nihče sam imel za Hrvata, ampak so vsi rekli, da so Srbi. Kot dodaja Pelagić, celoten "uporni narod ne bi žrtvoval niti prebite pare, ne svoje kokoši niti košare za krone in cesarstvo 'velikega' Zvonimirja in 'silnega' Dušana; žrtvoval pa je tako hišo kot imetje ter svoje in svoje družine življenje, hrepeneč po pravičnosti in svobodi, po sreči in napredku« (prav tam).

Bosansko vstajo je še dodatno zapletel prihod še enega pretendenta za bosanski prestol. Svojo četo je na bosansko ozemlje privedel Petar Karađorđević, znan kot Petar Mrkonjić, sin razkneza Aleksandra. V Ženevi in Parizu vzgojeni Petar Karađorđević je dobil vojaško izobrazbo v francoskih vojaških šolah, sodeloval je tudi v francosko-nemški vojni 1870-71. Iz Pariza je prišel v Bosno, da bi popravil svojo javno podobo plaboya in dvignil svojo politično ceno. To se mu je naposled tudi res posrečilo, a šele po majskem prevratu leta 1903, ko je postal kralj Srbije (Pavlowitch 1999: 109). Prihod Petra Karađorđevića in njegove čete v Bosno je uradno Cetinje ignoriralo, medtem ko je v uradnem Beogradu naredil »neprijeten vtis«. Zaradi njega je srbska vlada poslala bataljon stalne vojske na mejo z nalogo, da prepreči odhajanje prostovoljcev iz Srbije v njegovo vojsko, medtem ko je kapetanu Đoku Vlajkoviću ukazala, naj s svojimi prostovoljci nemudoma zapusti Bosno (Vuković 1925: 79-80, 175). Dinastični boji med Obrenovići in Karađorđevići so se v nekaj mesecih prenesli tudi v Srbijo. V Šumadiji je namreč prišlo do upora, katerega cilj je bil vreči Obrenoviće $s$ prestola in ponovno postaviti nanj Karađorđeviće (Milutinović 1953: 59).

Iz krščanskih dežel na Balkanskem polotoku, ki so bile še vedno pod osmansko upravo, so v drugi polovici 19. stoletja vse pogosteje prihajale novice o neusmiljenih grozovitostih, s katerimi so tlačili rajo. Poročale so o hudem divjanju »Turkov«, ki naj bi požigali in morili vse, kar jim je prišlo v roke, skrunili ženske, nabadali otroke na sablje in sploh ravnali s krščanskimi podložniki »hujši, kakor divje zveri« (Aléšovec 1878: 16). Vir večine teh novic

10 Vstanek v Hercegovini. Slovenski Narod, 11. 8. 1875: 2. 
so bili propagandni uradi balkanskih nacionalistov, ki so z njimi želeli zbuditi sočutje $\mathrm{v}$ evropskem javnem mnenju in z njegovo pomočjo pridobiti pomoč za »osvoboditev svojih zatiranih bratov«. Na evropskem zahodu je v tistem času prevladovalo mnenje, da so bile kristjanom v Osmanskem cesarstvu sistematično kratene človekove pravice (gl. npr. Freeman 1877: 202). Sčasoma so se kristjani naučili obrniti te zadržke v svoj prid. Sestavili so nekakšen seznam klasičnih grozot, povezanih z »odvratnim Turkom«, in ga predstavljali zahodnjakom (Durham 1920: 128).

\section{KRŠČANSKI SVET PROTI »TURŠKI KRVOLOČNOSTI«}

Vstajniki v Hercegovini in Bosni so šteli do 10.000 slabo oboroženih mož. Od vsega začetka so jim pomagali črnogorski prostovoljci, pridružili pa so se jim tudi prostovoljci iz drugih držav - Srbi, Rusi, Italijani, Poljaki, Francozi, med njimi se je znašla tudi ženska, Holandka Merkus (Rüstow 1877: 132). Koliko je bilo vseh prostovoljcev, ni znano, prav tako se ne ve, kako dolgo so sodelovali v vstaji. A sodeč po dopisu, priobčenem v Zastavi, ${ }^{11}$ jih ni bilo malo. Samo v Dubrovniku je bilo 3. decembra 1875 registriranih 284 Francozov, 390 Italijanov, 53 Angležev, dva Američana, en Šved, 83 Grkov in 22 Nemcev, ki so čakali, da bi se pridružili ustašem v Hercegovini. ${ }^{12}$ Švicarski zdravnik je Dubrovnik v času vstaje v sosednih pokrajinah opisal kot mesto »v odprti vojni« (Koetschet 1905: 24).

Novice o dogajanju v balkanskem delu Osmanskega cesarstva na jugovzhodu Evrope so najmočneje pretresle ves slovanski svet. Njihovi vedoželjnosti so stregli številni pisci in poročevalci s temačnimi slikami trpljenja krščanske raje pod "turškim jarmom«, "turških barbarov« in »turške krvoločnosti« in spletali sijajne lovorike vstajnikom, borcem "za svoje svete narodne pravice« (Pajević 1891: 114). Celo v slovenskih deželah so ljudje ne glede na to, ali so živeli v palačah in mestnih hišah ali v kočah po oddaljenih vaseh, čeprav geografsko odmaknjeni od prizorišč vstaje, napeto čakali na novice iz Hercegovine o uspehih vstajnikov (Aléšovec 1878: 3).

Ogorčeni bralci so dogajanje spremljali z nacionalistično pristranostjo in ga tudi pojasnjevali v skladu s svojo ideologijo dobrega in zla. To je pomenilo, da so bili v njihovih očeh "naši bratje« izključno in dosledno na pravi strani zgodovine, medtem ko so vsi tisti, ki se niso navdušeno skladali z njihovim pogledom, obveljali kar za etično problematične. Goriški Glas je septembra 1873 prinesel dopis iz goriške okolice, v katerem je pisec razpravljal o razlikah v pogledih na »ercegovinsko vstajo«. Člankar piše, da se je tedaj z vstajo ukvarjala ne le vsa evropska visoka diplomacija, temveč tudi slovenski »kmečki diplomati«. Kmetje

11 Srpski ustanak u Turskoj. Zastava, 22. 12. 1875: 2; Novak 1925: 119.

12 Kljub velikemu številu tujih prostovoljcev je Vasa Pelagić tožil, da slovanski narodi (Poljaki, Čehi, Slovaki, Kranjci in Hrvati) pred srbsko-turško vojno (1876) in rusko-turško vojno (1877) niso vsi skupaj poslali «ni stotine prostovoljcev na pomoč«, medtem ko je za njihovo pomoč v denarju navedel, da ni znesla niti 20.000 dukatov (Pelagić 1880: 77; prim. Milojković-Djurić 1994: 163). 
naj bi še vedno nekoliko živeli v dobri misli, da visoko izobraženi možje niso osvojili samo veliko znanja, temveč so si tudi »oblažili srcé, da hočejo vselej pravico i poštenost spoštovati, ter se povsod potegovati za njo«. Prav odnos do vstaje v Hercegovini pa naj bi pokazal, da ni vselej tako. Tamkajšnja vstaja kristjanov zoper »Turka« se je namreč pokazala kot »oster kamen poskušnje« za avstro-ogrske nemške in ogrske državnike, ki naj bi črtili Slovane in prijazneje gledali »na Turka nego na Slovana«. V člankarjevih očeh je bila hercegovska vstaja »boj za osvobodenje izpod morilnega turškega jarma, ki duši vsako kulturo«, zato bi jo avstro-ogrski državniki morali podpirati, a jim sovraštvo do Slovanov tega ni dovoljevalo:

Sto medvedov! da naš kmet v tem vprašanju vso diplomacijo deva v žakelj. Ne um, pa srce ima bolj izobraženo, zato ima sočutje s trpečim bratom. Pri njem ni več vprašanj, je li prav i uže čas, Turka zapoditi iz Evrope nazaj v njegovo domačijo, v Azijo; le o tem je še beseda, kdo naj na Jugu kraljuje. Zato bo pa tudi vsaka vlada, ki bi zoper ustajo zatiranih kristjanov govorila za Turke, dobila pri ljudstvu neizbrisljivo "črno piko. ${ }^{13}$

Po izbruhu vstaj v Hercegovini in Bosni so na vseh sosednjih območjih osnovali odbore za pomoč ustašem in njihovim družinam. Ustanovili so jih v Beogradu, na Cetinju, v Zagrebu, Kostajnici, Sisku, v Stari in Novi Gradiški, Zadru, Šibeniku, Splitu, Dubrovniku, Hercegnovem, Metkoviću, Trstu, pa tudi v Rimu, na Dunaju, v Pragi, Parizu in Londonu. ${ }^{14}$ Za ustanovitev takega odbora v Ljubljani se je zavzel še zlasti Jurčičev Slovenski Narod, ki je tako rekoč dnevno vabil bralce, naj pokažejo svojo slovansko solidarnost. V pozivu, priobčenem 3. avgusta 1875 na naslovni strani, je nepodpisani pisec (najverjetneje urednik Josip Jurčič) priznal, da je so imeli »mnogo narodnega davka» in da so bili »časi slabi«, a mogoče je, da bo podpora za hercegovske vstajnike in njihove družine "najvažniša izmej vseh, za katere smo podpisovali«. Pisec je navedel, da so v zadnji nemško-francoski vojni avstrijski Nemci veliko nabrali za nemške ranjence, in nato vprašal: "Ali bomo Slovanje menj srčni za svoje ubožneje brate? « ${ }^{15} \mathrm{~V}$ nadaljevanju se je zavzel, naj slovenske čitalnice prirejajo veselice za zbiranje denarne pomoči za hercegovske vstajnike. $\mathrm{Na}$ to so deželne oblasti na Kranjskem energično reagirale. Že na dan objave je deželna vlada odredila prepoved te številke Slovenskega Naroda in izdala tudi pisni ukaz okrožnim poglavarstvom in ljubljanskemu magistratu, da je zbiranje kakršne koli pomoči za vstajnike in njihove družine strogo prepovedano (Luković 1977: 124). Deželne oblasti svoje odločitve niso pojasnile, zelo verjetno pa je šlo za strah pred posledicami takih akcij: povzdig slovenske narodne zavesti in hkratno radikalizacijo slovenskih političnih zahtev (nav. delo: 125-126).

13 Iz goriške okolice. Glas, 3. 9. 1875: 2.

14 Po spominih kneza Nikole so ti odbori zbrali veliko pomoči. Zgolj odbor v Trstu je kupil za 104.967 forintov žita, medtem ko ga je Črna gora kupila za 28.877 forintov (Petrović Njegoš 1988: 306).

15 Slovenci! Slovenski Narod, 3. 8. 1875: 1. 
Prepoved, seveda, ni dosegla želenega cilja. Zbiranje prispevkov ni prenehalo, temveč so organizatorji akcije prepoved preprosto zaobšli. Kakor sta svoje bralce podučila Slovenski Narod konec julija in Slovenec na začetku avgusta 1875, prepoved zbiranja denarne pomoči vstajnikom ni nikomur preprečila, da bi poslal svoj prispevek dobrodelnemu odboru v Dalmacijo ali na Hrvaško. Pet dni po objavi prepovedi je Slovenski Narod natisnil članek "Vstanek v Hercegovini in nemško liberalno ministrstvo«, ki ga je podpisal Dr. K-č-. ${ }^{16}$ Avtor je priporočil »najglobočje sočutje z nesrečnimi našimi brati«, udeleženih v težkih in krvavih bojih "za krst častni in slobodo zlatno«, in vabil slovenske bralce, naj dajejo zanje prostovoljne prispevke, češ: "Ta čin človeštva ne more nam prepovedati vlada v Ljubljani, ker ga nijso prepovedale vlade ni v Zadru, ni v Zagrebu. Slovenci, bodimo kristjani, ljudje in Slovani! «17

Poleg pogostih pozivov na solidarno zbiranje prispevkov za vstajnike v denarju in oblačilih so se oglašali tudi pozivi za pomoč v orožju in prostovoljcih. Pisci so opominjali, da "strupena turška guja, katera grize na bratovem srcu, grize tudi na našem «. ${ }^{18}$ Pod pritiskom emotivnih podob trpljenja krščanske raje pod »turškim jarmom« je kranjska deželna vlada 3. septembra 1875 dovolila zbiranje "milodarov za nesrečne iz Turčije na avstrijska tla pribegle rodbine«. Na pobudo Josipa Jurčiča, Josipa Vošnjaka in Valentina Zarnika je bil ustanovljen Ljubljanski podpiralni odbor za sprejemanje in odpošiljanje daril za jugoslovanske brate, ki so bili krvav boj za »krst častni in slobodu zlato«, svoje žene, otroke in starčke pa so spravili v sosednjo državo, "da jih rešijo pred turško silo in divjostjo «. ${ }^{19}$

Avstro-Ogrska je bila uradno nevtralna do vstaje v obeh obmejnih pokrajinah: pošiljanje humanitarne pomoči je ovirala, izvoz orožja pa sploh prepovedala. Toda vzdolž dolge državne meje v Dalmaciji so živeli mnogi lojalni podaniki njegovega cesarskega, kraljevskega in apostolskega veličanstva, ki so ponosno nosili rdeče čepice z izvezenimi zlatimi začetnicami črnogorskega kneza Nikole. Zato še tako stroge prepoved niso mogle preprečiti vnašanje orožja in streliva v Hercegovino (Evans 1878: 69; Biankini 1925: 11; Stillman 1932: 29).

Slovensko, kakor slovansko sploh, časopisje v dvojni monarhiji se ni zadovoljevalo zgolj z izražanjem naklonjenosti do hercegovskih ustašev, pač pa so pozivali Slovane, predvsem Jugoslovane iz Srbije, Črne gore in Avstro-Ogrske, naj »bratom«v stiski vsestransko pomagajo. „Kad brat mora, da puškom sebe brani«, je pisal Slovenski Narod, "ne može brat, da mirnim poslovima sebe posvećuje« ${ }^{20}$ Goriški Glas je pozival jugoslovansko mladež - pri besedah in na taborih tako navdušeno za panslavizem - naj pokaže svoje navdušenje po zgledu na poljske in italijanske dijake in si »opaše britko sabljo i naj zasede šarca kraljeviča Marka«. ${ }^{21}$

16 Najverjetneje je bil to advokat dr. Kopač, član zagrebškega odbora za pomoč (gl. Vošnjak 1912: 1).

17 Dr. K-č-.Vstanek v Hercegovini in nemško liberalno ministerstvo. Slovenski Narod, 8. 8. $1875: 1$.

18 V-v., Vzajemno gorje Jugoslovanom. Slovenski Narod, 12. 8. 1875: 1.

19 Ljubljanski podpiralni odbor, Na pomoč! Slovenski Narod, 8. 9. 1875: 1; gl. tudi Vošnjak 1912: 56-58.

20 Vstanek v Hercegovini. Slovenski Narod, 10. 8. 1875: 2.

${ }^{21}$ Hercegovinska vstaja. Glas, 30. 7. 1875: 2. 


\section{CRNI MIRO}

$\mathrm{Ni}$ jih bilo malo, ki so se odzvali klicu na pomoč in kot prostovoljci odšli v Hercegovino. ${ }^{22}$ Bili so od vsepovsod, govorili najrazličnejše jezike, pripadali različnim narodnostim in veram, povezoval jih je en cilj: "prostovoljno žrtvovanje svoje krvi za svobodo Hercegovine ${ }^{23} \mathrm{~V}$ očeh sodelavca dnevnika The Times jih je bilo celo toliko, da se je zdelo primerneje reči, da pri vsem skupaj ni šlo toliko za "vstajo nemočnega domačega prebivalstva«, kot za "pravo invazijo slovanskih čet iz avstrijskih okrožij" (Gallenga 1877: 325), tj. Dalmatincev, Hrvatov in drugih podložnikov Avstro-Ogrske, »ki so na stvar hercegovskih vstajnikov gledali kot na svojo« (nav. delo: 339).

Čeprav avstro-ogrske oblasti niso dopuščale prehajanja prostovoljcev v vstajniške vrste in čeprav so bile prometne povezave s Hercegovino slabe, se je poleg državljanov dvojne monarhije s Hrvaške, iz Dalmacije in Slavonije hercegovskim ustašem pridružilo tudi več slovenskih prostovoljcev.

Prvi med njimi se je klicu »majke Slave« odzval Friedrich Hubmayer. V rani mladosti se je izučil za poštarja in dokaj mlad dobil službo v Egiptu in Sudanu. Med služenjem vojaške obveznosti v avstrijski vojski je dobil čin topniškega podoficirja in se seznanil s Srbi. Izkazal se je tudi s svojim talentom za strojništvo, saj je domislil več novosti in jih patentiral. Leta 1874 je bil delal kot tipograf v švicarskem mestu Chur, kjer se je seznanil s socialističnimi idejami in sočasnim delavskim gibanjem. V prvi polovici leta 1875 se je vrnil v Ljubljano in si našel zaposlitev v Bambergovi tiskarni. Pridobil si je zaupanje (slovenskih) tiskarniških delavcev, ki so ga 14. julija 1875 izvolili za predsednika društva ljubljanskih tiskarniških delavcev. ${ }^{24}$ Čeprav je bil iz nemške družine, za nemške člane društva ni bil sprejemljiv; očitali so mu, da je slovenski nacionalist. To naj bi potrjevala zlasti njegova izjava: „Zuerst bin ich Slovene, dann erst Buchbruder!“ ("Najprej sem Slovenec, šele potem knjigoljub «). ${ }^{25}$

Sredi druge polovice 19. stoletja je v Ljubljani narodni boj že prodiral v vse pore družbenega življenja in tamkajšnje društvo tiskarniških delavcev ni bilo izjema. To lahko razberemo iz dopisa v glasilu avstrijskih tiskarjev Vorwärts! Dopisnik je poročal, da je društvo tiskarniških delavcev v Ljubljani ostalo brez glave, ker je njihov novoizvoljeni predsednik odšel med vstajnike, da bi si kot poveljnik njihovega topništva "nabiral lovorike, katerih z naše strani ni dobil«. ${ }^{26}$

V društveno delo se je Hubmajer ponovno vključil po vrnitvi v Ljubljano leta 1877 (Luković 1977: 200). Na praznovanju 80-letnice delavskega društva v Ljubljani, ki so se ga udeležili številni delavci in njihovi prijatelji, med katerimi sta bila tudi deželni glavar

\footnotetext{
22 Aleksander Toman, Miroslav Hubmajer. Jutro, 7. 2. 1926: 10.

23 Srpski ustanak u Turskoj. Zastava, 22. 2. 1876: 1.

24 F. H., Laibach. Vorwärts!, 23. 7. 1875: 3.

25 Laibach. Vorwärts!, 6. 8. 1875: 3.

26 Laibach. Vorwärts!, 10. 9. 1875: 3.
} 
dr. Friedrich von Kaltenegger-Riedhorst in mestni župan Anton Laschan, so udeleženci prepevali skoraj izključno slovenske pesmi, narodna čustva pa so izražali tudi z burnim ploskanjem vojaški godbi, kadar je zaigrala kak »narodni komad«. Na prireditvi je imel Hubmajer »izvrsten govor«, v katerem je poudaril, da delavci hrepenijo po dveh idealih, to je po omiki in svobodi. Splošno izobraženost pa je navedel kot sredstvo, ki naj jim do tega cilja pomore. ${ }^{27}$

Hubmajer je delovno mesto v ljubljanski tiskarni Bamberg zapustil 30. julija 1875. Kupil si je revolver in doma rekel, da gre k sv. Katarini in da ostane tam čez noč, češ, da hoče videti sončni vzhod. ${ }^{28}$ Domov se ni vrnil, ker se je prek Dalmacije podal v Hercegovino in se vsega tri tedne po poku znamenite Nevesinjske puške pridružil vojvodi Mići Ljubibratiću in njegovim tovarišem pri samostanu Duži blizu Trebinja. ${ }^{29}$

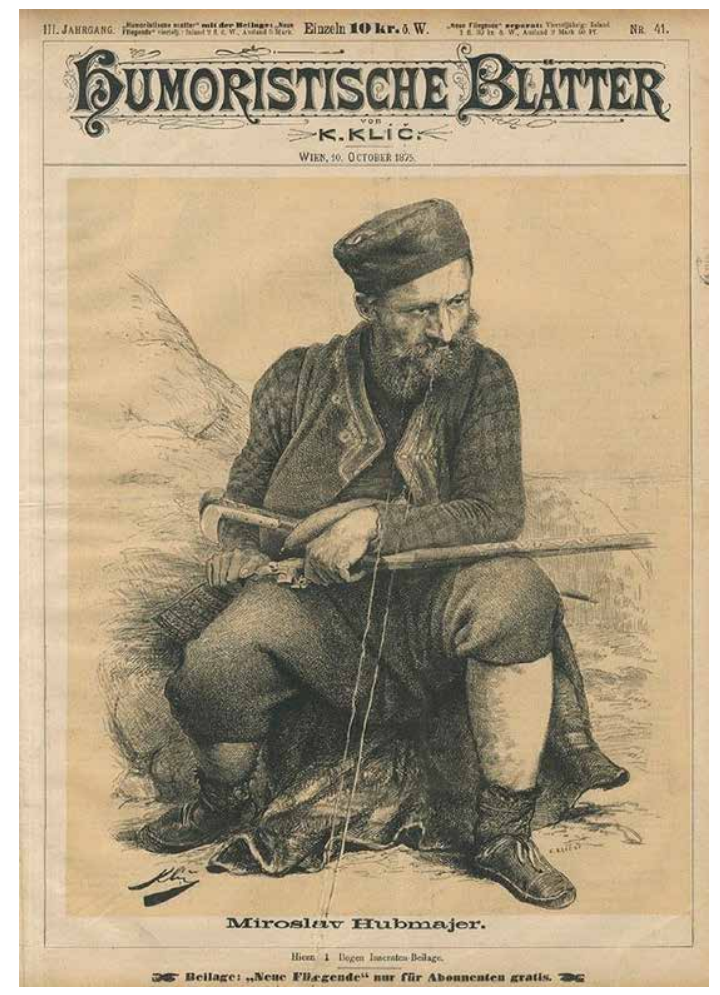

Karel Klíc: Miroslav Hubmajer. Humoristische Blätter, 10. 10. 1875.

27 Delavsko društvo v Ljubljani. Slovenski Narod, 31. 10. 1877: 4.

28 Miroslav Hubmayer †. Slovenski Narod, 4. 3. 1910: 2.; Luković 1977: 154-155.

29 Junak Hubmajer. Edinost, 11. 3. 1876: 4; Miroslav Hubmayer †. Slovenski Narod, 4. 3. 1910: 2; Rüffner 1877: 25; Mandić 1910: 10; Pero Uzelac, Črtica o Miroslavu Hubmayerju. Slovenski Narod, 22. 3. 1910: 1; Vošnjak 1912: 58; Aleksander Toman, Miroslav Hubmajer. Jutro, 7. 2. 1926: 10; Luković 1977: 154-155. 


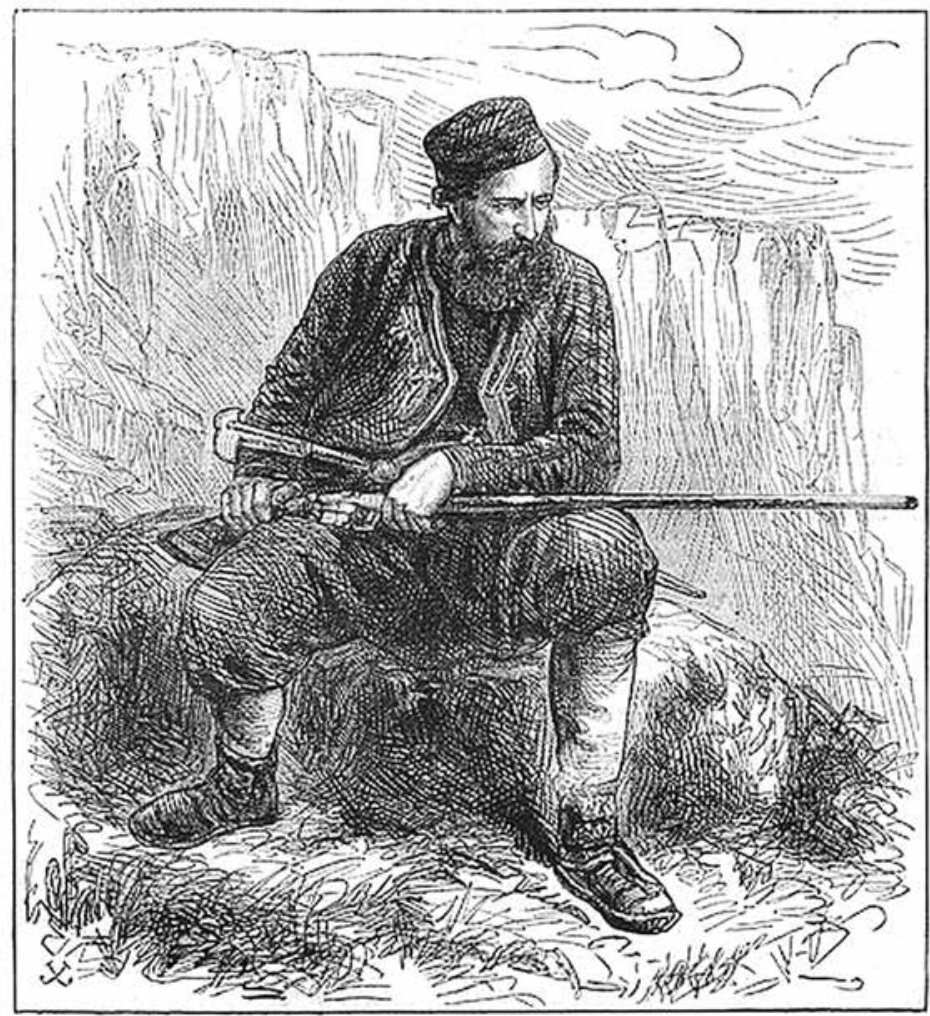

AN INSURGEST I.EADER, DUBROYNT,

Melton Prior: An Insurgent Leader, Dubrovnik. The Illustrated London News, 25. decembra 1875.

Med ustaši je svoje švabsko ime Friedrich oziroma Fritz poslovenil v Miroslav, med njimi je bil po svoji črni bradi znan kot Crni Miro. Zaradi izjemnega poguma je užival velik ugled in spoštovanje ter kmalu postal eden najslavnejših obrazov boja proti "turškemu" zatiranju. V drugi polovici 19. stoletja je njegova slava segla dlje in širše kot katerega koli drugega slovenskega sodobnika. O njem so objavljali novice časopisi v tako rekoč vseh evropskih jezikih, njegovo podobo so ovekovečili avtorji več knjig (gl. npr. Holeček 1878; Zimmermann 1878). Dunajski časopis Humoristische Blätter je 10. oktobra 1875 njegovo podobo natisnil na naslovni strani, zelo čislani ilustrirani list The Illustrated London News pa je njegovo upodobitev (delo slikarja in vojnega dopisnika Meltona Priorja) objavil v božični številki leta 1875 .

Hubmajer je pritegnil pozornost evropskih poročevalcev o hercegovski vstaji z junaškim obleganjem karavle Drijen. Vojvoda Ljubibratić je odšel na skupščino v samostan Kosirjevo; ob odhodu je postavil za glavarja Luko Petkovića in Rada Bajkovića, Hubmajerju pa je 


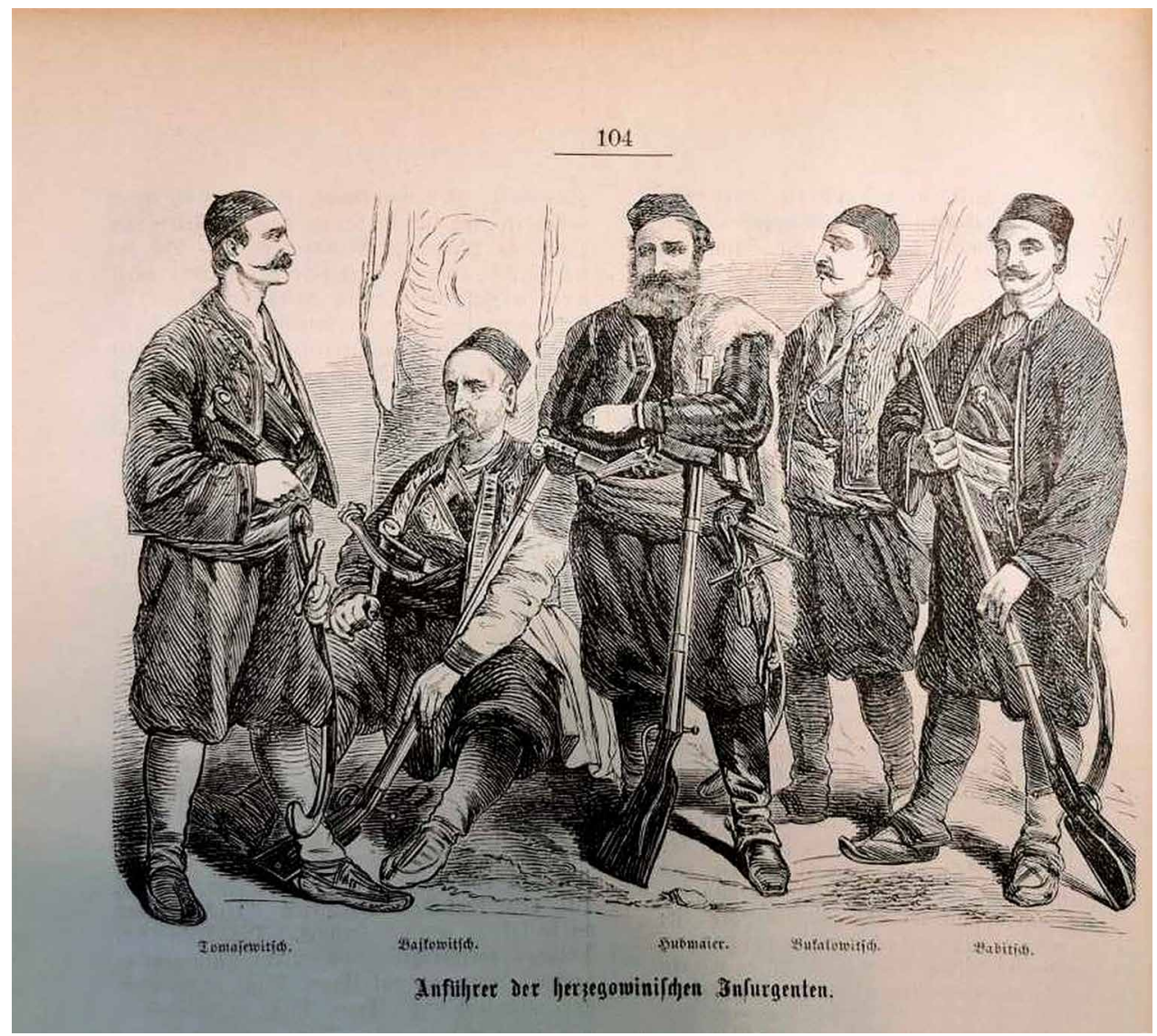

Vodje hercegovske vstaje (Moritz B. Zimmermann 1878. Illustrierte Geschichte des Orientalischen Krieges von 1876-1878. Wien, Pest, Leipzig: A. Harleben's Verlag).

zaupal poveljstvo nad malo četo na Drijeni. Ta je nato tri dni s svojo četo pazil, da noben "Turek« ni mogel iz kule ne ven ne noter (Hubmajer 1875a: 2). ${ }^{30}$ Ustaši so s streljanjem iz pušk skušali osvojiti utrdbo, a pri tem niso bili uspešni, ker niso imeli topniške podpore. Zato je Hubmajer šel pred karavlo in klical poveljniku Ahmetu Begoviću, naj pride iz trdnjave, da mu bo dokazal, kako se mu trese roka od strahu. Izzval ga je, naj strelja nanj, medtem ko bo on mirno stal, nezaščiten. Begović je res prišel in od daleč streljal na mirno stoječega Hubmajerja, a ga ni zadel (Holeček 1878: 59-60). Moštvo v trdnjavi kljub izzivanju ni sprejelo odprtega boja, čeprav so bili brez vode in imeli enega ranjenca. Da bi osvojil karavlo, se je četrtega dne obleganja Hubmajer pod plaščem noči odpravil s svežnjem dinamitnih palic podminirat trdnjavo. Pozno ponoči je prišel pod stolp, položil dinamit v strelno lino in prižgal vžigalno vrvico. Budni stražar v trdnjavi jo je opazil in hitro odvrgel

30 Miroslav Hubmajer, Piše 12. septembra iz Hercegovine. Slovenski Narod, 23. 9. 1875: 2. 
dinamitne palice; padle so kakih deset korakov stran od Hubmajerja. Zdaj so stražarji iz trdnjave začeli streljati za njim, »kakor bi zdivjali«, a je srečno pobegnil brez poškodb. ${ }^{31}$

Prizorišče je obiskal dopisnik dunajskega dnevnika Neues Wiener Tagblatt in svojemu listu telegrafično poročal o predrznem napadu na trdnjavo (Vošnjak 1912: 58-59). Poročilo je Hubmajerjevo slavo poneslo daleč prek meja Hercegovine. Številni evropski časopisi so poročali o njem kot o junaku, neustrašenem voditelju hercegovskih ustašev, uspešnem strategu, ki je »Turkom" prizadejal velikanske izgube. Vstajniki so navdušeno pripovedovali o njegovem junaštvu (Zimmermann 1878: 71). Hercegovska raja mu je pripisovala nadnaravno moč, češ, da je »čudežno zavarovan proti kroglam sovražnika«, in poleg Miće Ljubibratića je v kratkem času postal "narodni junak, nepremagljiv četovodja» (Toman 1926: 10). O njem so se pojavljala poročila, »ki so se glasila kakor bajke« (Toman 1926: 10), širile so se celo govorice, da je sam pognal v beg 2000 turških askerjev. ${ }^{32}$

Hercegovska vstaja je imela največji odziv na meji z neodvisno državo Črno goro, od koder je vstajnikom pritekala vsakršna pomoč, vključno z jajoši, prostovoljci. Vodje hercegovskih vstajnikov so se tudi večkrat obračali na črnogorskega kneza s prošnjami za pomoč. $\mathrm{Na}$ Cetinju so jih prijazno sprejemali in obljubljali pomoči; »a kjer politika govori, mora srce molčati, in to je bilo tudi tukaj« (Aléšovec 1878: 31). Velika večina Črnogorcev si je želela vojne s »Turki«, vendar je knez ni smel napovedati zaradi interesov velikih sil, predvsem Rusije in Avstro-Ogrske. Rusija mu je sporočala, da še ni čas za vojno, a naj se pripravlja nanjo, in ko bo pravi čas, mu bo že poslala podporo. Dvojna monarhija pa je budno spremljala dogajanje in vlogo majhne kneževine v njem, kateri je dala jasno vedeti, da ni pripravljena tolerirati nobenih vojaških aktivnosti v sosednji deželi. Knez Nikola je bil tako prisiljen prikrivati svojo vpletenost v hercegovsko dogajanje.

Konec avgusta 1875 sta na Cetinje odšla bližja sodelavca vojvode Ljubibratića Kosta Grujić in Miroslav Hubmajer, da bi od kneza izprosila pomoč. V črnogorski prestolnici ju je 9. septembra sprejel vojvoda Mašo Vrbica, črnogorski minister za notranje zadeve. Vrbica ju je - kot je zapisal Hubmajer v pismu staršem z dne 12. septembra - sprejel "prav prijazno«. Predstavil ju je tudi številnim »kapacitetam» in tujim gostom, ki jih je bilo tedaj na Cetinju »vse polno«. Ti so ju obsuli s številnimi vprašanji, posebno Hubmajerja. ${ }^{33}$ Povabil ju je tudi na večerjo, ki jo je priredil v svoji hiši za goste iz tujine. Med večerjo so Vrbici prinesli pismo iz Skadra s sporočilom, da prihaja tja velika osmanska vojska z nemajhno opremo. Hubmajer je vojvodo podrobno izprašal o Skadru in mu nato predlagal, da bi oba odposlanca še istega večera odšla v Skadar skupaj z nekaj Črnogorci.

31 Miroslav Hubmajer, Piše 12. septembra iz Hercegovine. Slovenski Narod, 23. 9. 1875: 2; Miroslav Hubmajer, Kar se je svetu javljalo. Slovenski Tednik, 20. 9, 1875: 4-5; Junak Hubmajer. Edinost, 11. 3. 1876: 4; Aléšovec 1878: 18; Zimmermann 1878: 87; Vošnjak 1912: 58; Grujić 1956: 69; Luković 1962: 123.

32 Slovenci in vstaja v Bosni. Častna zgodovinska preizkušnja bratstva v borbi zoper nasilje. Slovenski Narod, 16. 4. 1938: 6.

33 Z jugoslovanskega bojišča. Slovenski Narod, 23. 9. 1875: 2; gl. tudi Grujić 1956: 100. 
Tam bi ob zori napadli mesto. Pri tem bi bodisi padli za Črno goro ali osvojili Skadar. Po Hubmajerjevem razmišljanju bi se "Turki« prestrašili, saj bi jih napad presenetil; če bi napadli ustaši, pa odgovornosti tudi ne bi mogli preložiti na Črno goro. Vojvoda je njegov predlog sprejel z nasmehom, rekoč, da sprejema ponudbo, vendar šele za tedaj, ko bo pravi čas za to (Grujić 1956: 102).

Vojvoda Vrbica je vstajniška odposlanca vprašal, kakšno pomoč želita. Povedala sta, da želita dobiti revolverje in vsaj sto pušk zadnjač za potrebe tujih prostovoljcev kakor tudi črnogorska odlikovanja, da bi z njimi tuje prostovoljce zavarovali pred napadi domačih vstajnikov. Vrbica jim je obljubil, da se bosta naslednjega dne lahko »v vsem zadovoljena» vrnila v svoj tabor (Grujić 1956: 101-102). Rekel jima je še, da je že izdal ukaz za pomoč v možeh, a za orožje mora predhodno dobiti privolitev gospodarja in da naj počakata do naslednjega dne. 10. septembra popoldne jima je nato sporočil, da pušk in revolverjev nimajo, ker so jih pred nekaj dnevi razdelili vojski. Odposlanca sta se pozno popoldne razočarana poslovila. Ko sta že odhajala, pa so ju poklicali nazaj. Kakor je Hubmajer zapisal v pismu staršem v Ljubljano, mu je vojvoda Vrbica v knezovem imenu podaril v znamenje priznanja »jako lep revolver s pasom in pridejal 60 patronov «. ${ }^{34}$ Poleg revolverja mu je poklonil tudi svoj pas, ker ga Hubmajer ni imel, kakor ni imel niti revolverja, saj ga je izgubil. Po Grujićevem dnevniškem zapisu naj bi bil Vrbica to storil zato, »da bi ga podkupil« (Grujić 1956: 102-104). ${ }^{35}$ Ko se je leta 1876 Hubmajer vrnil v Ljubljano, je prinesel s seboj mnogo spominov, med njimi je bil tudi »krasen revolver", darilo črnogorskega kneza Nikole. ${ }^{36}$

\section{REŠEVANJE SLOVANSKIH BRATOV »IZ KREMPLJEV KRVOLOČNEGA TURKA“}

V začetku novembra 1875 se je Miroslav Hubmajer za kratek čas vrnil iz Hercegovine. Njegov obisk v Ljubljani je bil velik dogodek, o njem je v uvodnem članku poročal celo vladni dnevnik Neue Freie Presse. Po dopisnikovih besedah so Ljubljančani tega »Ur-Slave» sprejeli kot »zmagovitega generala«; bil je »človek dneva ${ }^{37} \mathrm{~V}$ sredo, 10 . novembra, so v steklenem salonu ljubljanske narodne čitalnice priredili večerjo v čast slovenskemu vstaškemu vodji. Dogodka se je udeležilo 61 pripadnikov ljubljanske nacionalistične inteligence. $\mathrm{Na}$ večerji je bilo veliko govorov in zdravic. Urednik Slovenskega Naroda Josip Jurčič je nazdravil

${ }_{34}$ Z jugoslovanskega bojišča. Slovenski Narod, 23. 9. 1875: 2; Miroslav Hubmayer †. Slovenski Narod, 4. 3. 1910: 1; gl. tudi Grujić 1956: 200; Luković 1977: 201.

35 Petko Luković je glede tega drugačnega mnenja. Po njegovem mnenju je knjaz Nikola podaril revolver Hubmajerju »ne le za njegova junaštva v borbi s Turki, temveč tudi zato, ker je uradno Cetinje zaupalo vanj« (Luković 1977: 201).

36 Miroslav Hubmayer †. Slovenski Narod, 4. 3. 1910: 1-2.

37 Eine bisher unentdeckte. Neue Freie Presse, 14. 11. 1875: 1. 
Hubmajerju kot možu dejanja; Valentin Zarnik Nj. Vel. cesarju iz rodbine onih Habsburžanov, ki so se stoletja borili zoper "Turka«; Fran Potočnik vsem, ki se borijo za »krst častni in slobodo zlatno«; Jožef Regali na enotnost in združitev Slovanov itn. Navzoči so z velikim navdušenjem sprejeli kratek Hubmajerjev govor, v katerem je izrazil trdno prepričanje, da si bo jugoslovanski narod gotovo priboril svobodno prihodnost, in napil vsem, ki s peresom ali besedo delajo za to. ${ }^{38}$ Po navedbah londonskega časopisa The Standard je Hubmajer med obiskom v Ljubljani prejel znatno vsoto denarja kot pomoč za vojaške operacije proti "Turkom«. Ta denar so zbrali med slovanskimi bankirji in trgovci v južni Avstriji. ${ }^{39}$

Vroče navdušenje, ki so ga Ljubljančani izkazovali Hubmajeru, pa ni prevzelo vseh. Dopisnik dunajskega dnevnika Neue Freie Presse iz Ljubljane je v poročilu o slavnostnem banketu hladno opomnil, da je bil Hubmajer avstrijski vojaški rezervist in ni uradno napovedal svojega odhoda v Bosno in Hercegovino, tedaj del Osmanskega cesarstva, Avstrija pa ni bila v vojni z Osmanskim cesarstvom. ${ }^{40}$ Konservativne Novice gospodarske, obrtniške in narodne so tri dni pozneje novembra jezno reagirale na ta produkt "judov in slovanožrcev«, označile so ga kot "zlobno izmišljeno laž«, kot »mastno kost za izstradane 'turške' liste in njihove dopisune ${ }^{41}$

Po nekajdnevnem bivanju v Ljubljani je Hubmajer odpotoval v Zagreb. Tudi tam so ga zelo lepo sprejeli, ljudje so ga hodili gledat »kot čudo«. ${ }^{42}$ Tri dni pozneje je Hubmajerju pripravila svečano večerjo zagrebška visokošolska mladina. Zbralo se je okoli 180 študentov in drugih gostov, navdušeno so pozdravili "junaškega boritelja za oslobodenje naših bratov v Hercegovini«, ki je bil pripravljenega žrtvovati tudi svoje življenje za rešitev slovanskih bratov »iz krempljev krvoločnega Turka«. ${ }^{43}$ Navzoči so v zdravicah poudarjali, da so se Jugoslovani borili za svojo svobodo, podobno kakor so se nedavno Italijani in Nemci. Bosna in Hercegovina sta bili nekoč del krone kralja Zvonimira, zato nima nihče pravice govoriti o "ustanku«, saj ljudje zgolj branijo svoje. Štiri stoletja so bili »Turki« strah Evrope, zdaj pa je nastopil čas, da dobijo povračilo za storjene grozote in se jih napodi nazaj v Azijo. Hubmajer je bil "jako zadržan« in je rekel le to, to da se Hercegovci bojujejo za svobodo vseh narodov. ${ }^{44}$

38 Banket Hubmajer. Slovenski Narod, 12. 11. 1875: 3; Srpski ustanak u Turskoj. Zastava, 16. 11. 1875: 1. - O ljubljanskem banketu v čast "vodji vstajnikov« (angl. Insurgent Chief) je poročal tudi londonski The Times. Po tem poročilu se je dogodka udeležilo nekaj slovenskih članov mestnega sveta, glavna zdravica pa je bila namenjena "avstrijski Dinastiji, ki bo, zvesta svojim tradicijam, zaščitila slovanske vstajnike«, medtem ko je Hubmajer napil enotnosti vseh jugoslovanskih narodnosti« (Austria and Herzegovina. The Times, 13. 11. 1875: 5).

39 One of the Leaders. The Standard, 10. 12. 1875: 7.

40 Eine bisher unentdeckte. Neue Freie Presse, 14. 11. 1875: 1.

${ }^{41}$ Pobirki iz časopisov. Novice gospodarske, obrtniške in narodne, 17. 11. 1875: 381-382.

42 Dopisi. Zastava, 11. (23.) 11. 1875: 2.

43 Iz Zagreba. Novice gospodarske, obrtniške in narodne, 24. 11. 1875: 388.

44 Novi Sad. Zastava, 9. (22.) 11. 1875: 3. 
Nekajtedensko bivanje med vstajniki v Hercegovini ga je precej razočaralo, saj med njimi ni bilo "nobenega reda ni discipline«, nikjer "se ne posluša nikogar, ki ukazuje « ${ }^{45}$ (Grujić 1956: 118; prim. Vuković 1925: 75; Petrović Njegoš 1988: 298). Ob odhodu iz Hercegovine mu je vojvoda napisal priporočilo, da je bil pri njem »dober vojak«(Grujić 1956: 118). Odšel v Bosno, da bi tam uresničil Ljubibratićeve načrte (Ekmečić 1973: 147). Tam je osnoval "tujsko legijo", sestavljeno iz "samih Kranjcev in katolikov" (Mrkonjić 1983: 64; gl. tudi Petrović Njegoš 1988: 312). Njegova namera je bila, da bi opustil majhne obmejne spopade in v središču v Bosni osvobodil del bosanskega teritorija (Grujić 1956: 196, 205, 211). Z odločnimi akcijami močne vojaške enote je želel prodreti v spodnji tok Neretve in tam združiti svojo enoto s silami vojvode Ljubibratića (Ekmečić 1973: 150).

Hubmajerjevo razočaranje nad hercegovskimi vstajniki je bilo najverjetneje posledica njegove domneve, da so nepismeni kmetje prijeli za orožje kot prvoborci panslavizma ali svetovne revolucije (Evans 1877: 336). Hubmajerjeva predanost boju za izboljšanje delavskih in narodnih pravic, ki jo je izkazal kot predsednik društva tiskarskih delavcev v Ljubljani, in njegova visoka načela slovanske vzajemnosti, zaradi katerih se je pridružil vstaji v Hercegovini, niso bila v skladu s pričakovanji upornih kmetov, ki so prijeli orožje, da bi si priborili nekaj svoboščin in ugodnejše razmere za svojo poljedelstvo. Neskladje med pričakovanji in vstajniško stvarnostjo pri Hubmajerju ni le sprožilo razočaranja, temveč ga je tudi ločilo od lokalnih ustašev.

Hubmajer je bil pripadnik liberalne smeri slovenskega narodnega gibanja, navdušen privrženec "misli slavjanske«, za katero si je srčno želel, "da pobedonosno nadkrili vse sovražnike slovenskega naroda«. Med svojim sodelovanjem v vstajah v Hercegovini in Bosni in pozneje v Srbiji in Pirinski Makedoniji je deloval »vedno v slavo mile majke Slavije!«. ${ }^{46}$ Ko se je pridružil vstajnikom v Pirinski Makedoniji je njegov odhod Slovenec komentiral takole: "Naš Hubmajer biva že med njimi, ker njemu kri ne dopusti, da bi doma ostal, če na Balkanu slovanske puške pokajo «. ${ }^{47}$

\section{VSTAJNIŠKI PARLAMENT}

Vstaja v Hercegovini je izbruhnila brez centralnega vodstva. Pomanjkanje tega je posebej očitno prišlo do izraza sredi meseca decembra 1875, ko so se vstajniki umaknili v svoja zimska zaklonišča. Po opisu francoskega popotnika Charlesa Yriartea je bilo tedaj poveljevanje tako razdrobljeno, da je bilo težko celo našteti odrede in vodje (Yriarte 1981(1876):

45 Gavro Vuković je zapisal besede nekega Bjelopavlića, ki je po vrnitvi z bojišč pred knezom pripovedoval »neverjetne stvari proti popu Žarku in njegovi družini, da so vojakom jemali plen in rop, ga v denar pretvarjali in pošiljali na svoje domove, kakor tudi, da so enako počeli s prispevki, prejetimi od raznih komitejev iz Srbije« (Vuković 1925: 75-76).

46 Miroslav Hubmajer, Telegram. Slovenski Narod, 12. 7. 1893: 3.

47 Iz Belgrada. Slovenski Narod, 24. 10. 1880: 3. 
281-282). A če ni bilo jasno, kdo pije in kdo plača, je bilo jasno, da vstaja brez organizacije nima nobenih možnosti za uspeh, zlasti ne v bojnih operacijah. Da bi vsi ustaši poenotili za "bratski sporazum», so za 16. in 17. decembra 1875 sklicali skupščino v vasi Jamnica blizu meje. Po poročilu svojega dopisnika je londonski The Times poročal, da je prav Hubmajer s pomočjo Omladine uspel sklicat ta vstajniški komite. ${ }^{48}$

$\mathrm{Na}$ skupščini je poslala svoje zastopnike večina večjih vasi iz vse Bosne, od Bihaća do Drine. Najprej so obravnavali reforme, ki jih je Porta ponujala kot izhod iz zagate, in jih zavrnili kot nepopolne in neuresničljive. ${ }^{49}$ Nadalje so obravnavali vprašanje, ali naj nadaljujejo z vstajo tudi prek zime. Po dolgi razpravi so se odločili, da nadaljujejo z oboroženo vstajo, vse dokler osmansko gospostvo ne bo odpravljeno. Predstavniki vstajnikov so soglašali tudi, da je treba preseči strankarska rivalstva in ustvariti enotnost v gibanju, in potrdili tudi odločitev o napadu na Tursko Kostajnico. Za uresničevanje tega sklepa so imenovali nov vstajniški odbor, ki je prevzel vlogo nekakšne provizorične vlade, za glavnega vojvodo pa so izbrali Miroslava Hubmajerja, med vstajniki čislanega zaradi njegovega poguma in nesebične navdušenosti za stvar. ${ }^{50}$

Glede izbire glavnega vojvode je bila skupščina manj enoglasna. V razpravi je padel predlog, da naj bi to postal Petar Mrkonjić, "Srb in Karađorđev vnuk, ki se je odlikoval tako v francosko-pruski vojni kot v bojih tedašnjih vstajnikov«. Privrženci beograjske vlade in dvojne monarhije so predlogu nasprotovali, češ, da ne marajo služiti njegovim zasebnim interesom, ker bi bil antagonizem med Obrenovići in Karađorđevići usoden za uspeh. Od Petra Mrkonjića so zahtevali, da se mora skupaj s svojo četo v osmih dneh umakniti z bosanskega ozemlja, ker je njegova navzočnost škodljiva za vstajo. Za glavnega vojvodo ustašev so nato izbrali Miroslava Hubmajerja. ${ }^{51} \mathrm{~S}$ tem pa spet niso bili

48 From our Austrian Correspondent. Servia and Bosnia. The Times, 6. 1. 1876: 4.

49 Odklonilno stališče do Portinih reform so imeli tudi bosanski begi. Po poročanju novosadske Zastave je v Travniku 8. februarja 1876 potekala še skupščina bosanskih begov, ki je sklenila zavrniti reforme, po potrebi tudi z orožjem. Na tej skupščini je bil sprejet tudi sklep, da bodo »sprejeli« in »življenje pustili« samo tistim podložnikom, ki svojemu begu dajejo polovico prihodka, ker so kristjani prejšnje leto zapustili svoje hiše in pustili pridelek nepobran na poljih, s čimer so oškodovali svoje zemljiške gospode, ker jim niso dali ne tretjine niti desetine (Besarović 1951: 102).

50 Herzégovine. Le Presse, 19. 12. 1875: 2; Jugoslovansko bojišče. Slovenski Narod, 21. 12. 1875: 2; Srpski ustanak u Tursko. Zastava, 10. (22.) 12. 1875: 2; Politični pregled. Soča, 23. 12. 1875: 4; Zunanje države. Glas, 24. 12. 1875: 3; From our Austrian Correspondent. Servia and Bosnia. The Times, 6. 1. 1876: 4; Krasić 1884: 87; Ivić 1918: 48; Petrović 1924: 15; Čubrilović 1930: 140-141; Slipičević idr. 1952: 128; Ekmečić 1973: 144-146; Mrkonjić 1983: 55-57.

51 S tem v zvezi je zanimivo poročanje dopisnika londonskega The Standard, po katerem je Hubmajer zastopal črnogorske interese. Pisma, poslana iz njegovega tabora v Jamnici, so bila namreč »polna pritožb čez intrige dveh srbskih strank« (The Insurrection in Herzegovina. The Standard, 27. 1. 1876: 3). Povsem drugačen je pogled nekaterih zgodovinarjev, po katerih je v Jamnici vodstvo vstaje prevzela "odborniška stranka«, ki je imela večino v tej skupščini in so jo imenovali "Milanova stranka" (Ivić 1918: 49; Kapidžić 1953: 261; Ekmečić 1973: 147). 
zadovoljni vsi. ${ }^{52}$ Nekateri so mislili, da bi za glavnega vojvodo morali izbrati koga iz vrst "tolikih dobrih junakov, rojenih Bošnjakov«. Dva črnogorska udeleženca skupščine sta tedaj menda glasno protestirala, držeč handžarja: "Zakaj nam dajete za vojvodo Švaba?» (Krasić 1884: 86).

Iz poročil, ki jih je prinašalo sočasno časopisje, lahko razberemo, da je bil Miroslav Hubmajer nezadovoljen z delom nekaterih odborov za pomoč vstaji, zlasti z odborom v Kostajnici, česar tudi ni skrival. Tako pa se je hudo zameril nekaterim članom odbora, zlasti Vasi Pelagiću. Med Hubmajerjem in nekaterimi vstajniškimi voditelji je prišlo do napetosti, skoraj do sovražnosti. Te so se pokazale že ob njegovem prihodu v severozahodno Bosno, njegova izvolitev za glavnega vojvodo jih je še okrepila, čeprav se na skupščini Hubmajer ni opredelil za nobeno od političnih smeri, zastopanih med vstajniškimi voditelji. Pri Petku Lukoviću je prišla do izraza "stara bolezen, ki se je izživljala v političnih prepirih«, zlasti med privrženci kneževine Srbije in med zagovorniki avstroogrske okupacije Bosne in Hercegovine. Iz nje so pognale intrige, podtikanja, obtožbe in podobno, kar je vstajo vse bolj razjedalo in hromilo. Sodobno evropsko časopisje je kot največjega intriganta proti Hubmajerju označilo Vaso Pelagića. Hubmajer je takoj po prihodu v Kostajnico skritiziral delo tamkajšnjega odbora za pomoč vstajnikom. Člani odbora, zlasti Vasa Pelagić, so na njegovo kritiko reagirali z veliko mero nestrpnosti, prizadevali so si, da bi ga čimprej vrgli z vodilnega položaja in pregnali iz vstajniških vrst (Krasić 1884: 87; Ivić 1918: 50; Karanović 1921: 35-36; Luković 1977: 193-194).

Hubmajer je v pismu 11. januarja 1876, poslanem iz Glavnega tabora na naslov Slovenskega Naroda (ta ga ni objavil), celo zapisal, da je bil pred skupščino v »zelo težkem položaju« zaradi nezaupanja s strani »stranke Karagjorgjeviča«, ki je prizadevno razširjala zablode in nesoglasja; tako je bil »kot v megli« in ni vedel, komu naj verjame in kaj naj ukrene. V pismu je z imenom omenil Vaso Pelagića in Sima Bilbijo. ${ }^{53}$

O naklepih zoper Hubmajerjevo življenje je 22. decembra 1875 podrobno poročala tudi novosadska Zastava. Pisec je poročal o vstajniku Miodragoviću, ki je dobil nalogo, da gre v Glino in prinese vse stvari, ki so bile tam, v Žirovac, kjer je bil Hubmajerjev zastopnik. Ko se je vrnil, je prišel pop Ostojić in Miodragoviću povedal, da je iz Gline prišlo pismo, v katerem piše, da je treba Hubmajerja odstraniti "na kakršen koli način«. Poročevalec, močno začuden nad "slogo srbsko«, je pojasnil, da je bil cilj odstranitve Hubmajerja, da bi vodstvo vstaje prevzel kak drug poveljnik iz vrst bosanskih vstajnikov, in napovedal, da bodo Hubmajerja ubili ali v Kostajnici ali v Jamnici, kjer je bil tabor Petra Mrkonjića.

52 Jugoslovansko bojišče. Slovenski Narod, 21. 12. 1875: 2; Jugoslovansko bojišče. Slovenski Narod, 22. 12. 1875: 1; Srpski ustanak u Turskoj. Zastava, 10. (22.) 12. 1875: 1; Zunanje države. Glas, 24.12. 1875: 3; Srpski ustanak u Turskoj. Zastava, 23. 1. 1876: 1; Vukićević 1922: 12, 14.

53 Miroslav Hubmayer, Pismo Slovenskom Narodu (Glavni tabor, 1876). Izvirnik pisma hrani Narodna in univerzitetna knjižnica Ljubljana, Rokopisni oddelek, Jurčičeva zapuščina, fasc. 27. 


\section{NAPAD NA TURSKO KOSTAJNICO}

Kar zadeva vojaške operacije, je jamniška skupščina sklenila izvesti napad na Tursko Kostajnico. Tako bi namesto gverilskih akcij začeli osvobajati večje ozemlje. Glede na znana dejstva je Petko Luković sklepal, da je bil Hubmajerjev cilj z odločnimi akcijami in močnimi vojaškimi silami prodreti v revir spodnjega toka reke Neretve, kjer naj bi se njegova enota združila z Ljubibratićevimi silami (Luković 1977: 191).

Konec leta 1875 in na začetku januarja 1876 je bosansko mejo prekoračilo večje število prostovoljcev iz tujine, zlasti iz Srbije. Bili so dobro izurjeni in opremljeni, Hubmajer pa jih je oborožil z dobrim orožjem. Hubmajer je tako kot pred tem že Petar Mrkonjić veliko pričakoval od prostovoljcev, med njimi je bilo le malo bosanskih beguncev. Ti so se v času v času oblikovanja nove čete v glavnem »držali apatično« in čakali, da četa nekaj stori na bosanskem ozemlju in da se potem še sami vrnejo (Ekmečić 1973: 150). Dan po koncu jamniške skupščine so prek avstro-ogrske meje v vstajniški tabor pritihotapili top, vlit po Hubmajerjevem naročilu, skupaj z laveto in strelivom. Menili so, da bodo z njim lahko napadli tudi mesta, kakor so Novi, Kostajnica, Prijedor, ker »Turki« v vsej severni Bosni niso imeli nobenega "za odprto bojno polje sposobnega kanona«. Zemeljski nasipi okoli trdnjavic so bili bodisi prazni ali pa so po njih stali "stari kašljavci še iz časov generala Lavdona«. Po zapisu goriškega Glasa sta taktična organizacija in vojaška disciplina zadnji čas med vstajniki »lepo napredovali«. Prvotne »brezredne vstaške trume« so se preoblikovale $\mathrm{v}$ redne čete s svojimi nad-in podpoveljniki, s stalnim poveljstvom in z vojaškimi znamenji, kar je obetalo, da bodo »bojni vspehi vstašev čem dalje sigurnejši «.54

Glavni napad na Tursko Kostajnico naj bi vodil Hubmajer, pomagale pa naj bi mu še tri manjše enote (Ivić 1918: 49; Čubrilović 1930: 82, 141; Ekmečić 1973: 146). Na prvi dan leta 1876 so v vstajniškem glavnem taboru s puškami odzadnjačami oborožili več sto ljudi. Hubmajer je stopil prednje, okrog njega vse četovodje, pop Đorđe Karanović je začel brati molitev. Po koncu molitve je vprašal ustaše, ali hočejo "v ogenj in vodo za narodno svobodo?« - »Hočemo!« je zadonelo z vseh strani. Pop je v odgovor izrazil željo, »naj bog živi našega vojvodo!«, in spet je odmeval dolgotrajni "Živio! «. ${ }^{55} \mathrm{Na}$ Bogojavljenje, 6. januarja, sta bila blagoslov vstajniškega praporja in zaprisega bosanske vojske. Molitve so brali trije svečeniki, ki so vojake zaprisegli vojski z besedami:

Prisegamo pri najvišnjemu bogu, stvarniku neba in zemlje, da bomo zvesti našemu slavnemu bosanskemu narodu in od njega nam postavljenemu vojvodi Miroslavu, ščitili narodne interese v vsakem smislu in uporabili vse možne sile za osvoboditev naroda. Našo zastavo in naše starešine ne bomo zapustili niti v največji stiski, pošteno in junaško jih bomo branili tako na zemlji kot na vodi

54 Zunanje države. Glas, 24. 12. 1875: 3.

55 Iz ustaškog glavnog tabora. Zastava, 11. (23.) 1. 1876; 1. 
ter raje umrli, kot da bi se izneverili naši zastavi; tako nam bog pomagaj, častni križ, sveti evangelij. Oče in sin in sveti duh amen. ${ }^{56}$

Po zaprisegi je vstajnike spodbujal še Vasa Pelagić, češ, »tisti, ki vzdrži boj, je potomec Miloša Obilića, tistemu pa, ki izda, mu bo prekleto ime in potomstvo«. Nadaljeval je, da se je Srbija osvobodila in je nastopil čas, da tudi bosanski narod strese jarem s sebe. Po Pelagićevem govoru so prapor predali v ruke vojvodi Miroslavu Hubmajerju. Napovedal je nov sestanek čete v nekaj dneh na istem mestu, ko bodo prapor ponesli v Bosno, "v našo pravo domovino, da si svobodo zadobimo «. ${ }^{57}$

Do sredine januarja 1876 se je v Hubmajerjevi četi zbralo do 500 mož, od katerih je bila približno polovica graničarjev s hrvaške strani in bosanskih beguncev, preostali pa so bili tuji prostovoljci, v glavnem srbski. Zaradi pestrega sestava čete in barvitega zunanjega videza njenih pripadnikov so jo posmehljivo imenovali »legija stranaca» (»tujska legija»), kar je bilo sicer tudi njeno uradno ime. Njena sestava sama po sebi kaže na to, da je bilo bosansko vodstvo vstaje tudi po formalni strani pod vplivom Miće Ljubibratića. V Hercegovini je namreč tudi on hotel sestaviti "stranačko legijo in z njo osvoboditi Bosno (Grujić 1956: 196, 205, 211). Čeprav je bilo to razmišljanje rezultat izkušnje, da neorganizirane kmečke množice niso sposobne osvajanja bosanskega ozemlja, pa je bilo v njem izraženo tudi nezaupanje vodstva gibanja $\mathrm{v}$ domačine in posledično iskanje glavne opore $\mathrm{v}$ prostovoljcih iz tujine (Ekmečić 1973: 150).

Dva tedna po zaprisegi je Hubmajer zbral 450 mož in jih popeljal po poti iz Jamnice proti Dvoru. Na čelu kolone so nosili prapor, med pohodom sta izmenoma igrala trobentač in tamburaš. Na pot so odšli, ko se je znočilo, z namenom, da bi jih pri Kuljanu brodarji iz Hrvatske Kostajnice prepeljali čez reko Une (Ivić 1918: 52; Čubrilović 1930 I: 82; Ekmečić 1973: 151; Luković 1977: 192-194). A ko je Hubmajerjeva četa prišla do brega Une, brodov ni bilo. O dolgem zimskem nočnem pohodu je prinesla poročilo očividca novosadska Zastava. Po navedbah poročila naj bi jih na dogovorjenem mestu pričakala dva vnaprej plačana broda. Organizacija prevoza je bila v rokah člana kostajniškega podpornega odbora Vase Pelagića.

Pelagić je zatrjeval, da je vse urejeno, čeprav »ni bilo ničesar «. ${ }^{58} \mathrm{O}$ tem, da je pohod propadel zaradi intrig bosanskega odbora, je enoglasno poročalo vse evropsko časopisje. ${ }^{59}$ Kakor je za tržaško Edinost povedal Hubmajer sam, je šlo za namerno dejanje »izdajice Pelagiča, kateri je sporazumljen z Karagiorgievičem, da bi zanj delal in ga zopet na srbski prestol spravil ${ }^{60}{ }^{60}$ Hubmajerjeve navedbe se skladajo s poročilom v dunajski Politische

\footnotetext{
56 Srpski ustanak u Turskoj. Zastava, 28. 1. 1876: 1.

57 Srpski ustanak u Turskoj. Zastava, 16. (28.) 1. 1876: 1.

58 Dok diplomacija plete konce. Zastava, 20. 1. (1. 2.) 1876: 1.

59 Gl. npr. Bosnia and Herzegovina. The Times, 24. 2. 1876: 5; Herzegovina. The Standard, 24. 2. 1876: 3 .

${ }^{60}$ Junak Hubmajer. Edinost, 11. 3. 1876: 4.
} 
Correspondenz, prenesenim v novosadski Zastavi, da je zaradi ponesrečenega pohoda na Tursko Kostajnico »nekdanjemu arhimandritu banjaluškem in sedanjem vodji Pelagiću uspelo potisniti Hubmajerja z njegovega mesta in mu pripraviti usodo Ljubibratića«. ${ }^{61}$

Dober mesec pozneje je Zastava prinesla še videnje dogajanja s strani tistih, ki so po neuspelem pohodu prevzeli vodstvo bosanske vstaje. Bošnjaki so Hubmajerja z njegovim "rojem tujih pustolovcev« pregnali, ker so »sramotili« vstajo. Vodstvo vstaje sta prevzela pop Karan in Dučić, ker stvari niso potekale na zadovoljiv način, saj odbori za pomoč vstajnikom niso več zmogli zbrati dovolj denarja. S prostovoljci so namreč imeli več stroškov kakor $s$ tisoč »Bošnjaki« - samo za Hubmajerjevo »telesno gardo«, sestavljeno iz šestnajstih ljudi, naj bi bilo v treh tednih izdanih skoraj 3000 frankov. ${ }^{62}$

Kakor koli že, udeleženci pohoda niso mogli prečkati Une in so morali prenočiti v bližnji vasi, in to brez hrane. Te niso nosili s seboj, saj so pričakovali, da jo bodo našli v Kostajnici, za katero so bili prepričani, da jo bodo osvojili, ker so bili vsi dobro oboroženi, s seboj pa so imeli tudi top. Poleg tega se je osmanska vojska pomaknila v smeri proti Bužimu, misleč, da bo napad usmerjen tja. ${ }^{63}$ Nejevoljni Hubmajer je nameraval oditi v Zagreb z zahtevo, da sam prevzame celotno vodstvo vstaje, brez sodelovanja Pelagića in drugih, "ki niso sposobni dokončati niti najmanjše malenkosti«. ${ }^{64}$ Niti to se ni izšlo po njegovih željah. Na svečnico zvečer ga je v gostilni v Bešlincu skupaj z 24 vstajniki presenetila avstrijska vojaška straža, jih razorožila in odpeljala v Dvor, od tam pa v internacijo v Caprag. Hubmajerju se je posrečilo izmakniti, vrnil se je v Hrvatsko Kostajnico, a tam je moral predati stvari odborovem zaupniku Simi Bilbiji, saj so ga takoj po "porazu« razrešili s položaja glavnega vojskovodje (Krasić 1884: 89). Tako se je izjalovil poskus jamniške skupščine, da bi vstajnike povezali pod enim skupnim vodstvom in osvojili del bosanskega ozemlja, od koder bi se vstaja lahko širila (Ekmečić 1973: 152).

Ponesrečenega pohod na Tursko Kostajnico po mnenju zgodovinarja Milorada Ekmečića ne gre pripisati zgolj vojaški intervenciji avstro-ogrskih oblasti in nesposobnosti vstajniškega vodstva. Glavni razlog je bilo dejstvo, da jamniška skupščina ni uspela uresničiti postavljenega cilja: poenotenje posamičnih političnih smeri v vstaji. Zato Ekmečić ocenjuje, da bi se razpad Hubmajerjeve vojske nadaljeval takoj po njenem ognjenem krstu, tudi če bi prekoračila mejo (Ekmečić 1973: 152).

Kot je poročal Slovenec, je razočarani Hubmajer zapustil vstajnike v Bosni, »kjer so mu sebični nameni nekterih vodij delali zapreke vsake baže«, in se preko Trsta in Benetk podal v Švico. Poročevalec je dodal, da mu tega nihče ne zameri, če premisli, »kako hudo je moralo njega, kterega je k ustajnikom gnala le čista in blaga misel, po svojih močéh pomagati jim

${ }^{61}$ Dok diplomacija plete konce. Zastava, 1. 2. 1876: 1.

62 Srpski ustanak u Turskoj. Zastava, 5. 3. 1876: 1.

63 Kostajnica. Zastava, 30. 1. 1876: 2; gl. tudi The Insurrection in Herzegovina. The Standard, 27. 1. 1876: 3; Luković 1977: 193.

${ }^{64}$ Kostajnica. Zastava, 30. 1. 1876: 2. 
do dosege človeških pravic in do svobode, zbosti to, ko je videl, da tudi tu malopridni ljudje reveže hočejo rabiti za svoje namene«. ${ }^{65}$ Takrat se ni vrnil v Ljubljano, temveč je odšel v Chur, kjer so mu švicarski kolegi priredili pozdravni večer (Kermavner 1966: 628). Na poti proti Švici pa je »naš rojak poln zaslug, naš junak« moral trpeti pomanjkanje. Tržaški Slovenci mu namreč »niso dali kebra« in je moral svoje reči prodati ali zastaviti, da je mogel nadaljevati pot. ${ }^{66}$

\section{ZIDANJE SKADRA}

Tekmištvo med Obrenovići in Petrovići je imelo od začetka hercegovske vstaje do junija 1876 velike posledice za vstajo. Poslabšali so se tudi odnosi med Srbijo in Črno goro. Že sama misel na to, da Srbija pretendira na Hercegovino, je bila v Črni gori videti ne le mabsurdna, temveč tudi žaljivaw. Hercegovina je postala kislo jabolka spora med Beogradom in Cetinjem, ker jo je knez Milan skupaj z Bosno želel priključiti Kneževini Srbiji. ${ }^{67} \mathrm{~S}$ Hercegovino pa je imela svoje načrte tudi majhna gorska kneževina. Če kateri od vojvod ali vstajnikov ali prostovoljcev s katere koli strani ne bi izražal, delal in mislil, da Hercegovine ni treba priključiti Črni gori, je veljal za izdajalca in je bil postavljen pred hitro sodišče (Vuković 1925: 147; Jovanović 1977: 207).

Po poročilu Laibacher Zeitung se je politična zavist med Srbijo in Črno goro prenesla tudi na prizoriš̌ce hercegovske vstaje in ustvarila »veliko neslogo« med vstajniškimi prvaki. Medtem ko so se privrženci srbske stranke jezili, ker so prostovoljci s Cetinja odhajali na pomoč samo tistim ustaškim vodjem, ki so bili izrecni privrženci kneza Nikole, so se simpatizerji Črne gore pritoževali čez srbske odbore zaradi pomoči vstajnikom, ker so podpirali samo tiste ustaške vodje, ki so se borili za interese Kneževine. ${ }^{68}$

Po majskem prevratu leta 1903 so se na srbski prestol vrnili Karađorđevići in krona na glavi kralja Petra I., nekdanjega ustaškega vojvode, je povsem na novo osvetlila preteklost, vključno z Mrkonjićevim vojskovanjem v Bosni. Zdaj je bilo videti, da je bil prav on "najprimernejša oseba, ki bi mogla prevzeti vrhovno poveljstvo nad vsemi vstajniki« (Ivić 1918: 47). Ob dvajsetletnici osvoboditve in ujedinjenja troimenega naroda se je to dejansko uresničilo. Beograjska Politika je takrat objavila, da je po jamniški skupščini »na čelo vstaje stopil vojvoda Petar Mrkonjić«, Miroslav Hubmajer, ki se je v Bosni in Hercegovini izkazal z »izrednim junaštvom «, pa je »v krogu svojih bratov Srbov in Bosancev zasedel položaj vojvode ene čete. «"

65 Hubmajer. Slovenec, 23. 3. 1876: 4.

${ }^{66}$ Junak Hubmajer. Edinost, 11. 3. 1876: 4.

${ }_{67}$ France Jaroslav (Štrukelj), Zgodovina Črne Gore. Slovenec 3 (134-140, 145-148), 1875; Wertheimer 1913: 252; Vuković 1925: 84, 170; Seton-Watson 1931: 14; Radonić 1938: 221; Milutinović 1953: 38, 48; Luković 1977: 58.

$68 \mathrm{Zu}$ den Vorgängen in der Herzegovina. Laibacher Zeitung, 12. 11. 1875: 2009.

69 M. Milanović, Sedamdesetogodišnji jubilej »Slovenskoga Naroda«, najstarijeg dnevnika Slovenskog Juga. Politika, 21. 4. 1938: 12. 
Zgodba o vojvodi Mrkonjiću ni bila več zgodba o nekom, ki iz sebičnih razlogov ovira narodno osvoboditev, pri čemer mu je menda »sama Turčija pomagala z denarjem «, ${ }^{70}$ temveč so se po njegovi izvolitvi za srbskega kralja leta 1903 o njem spletle mnoge legende (gl. npr. Dimnik 1922: 78-80). V teh romantičnih zgodbah Petar Mrkonjić nastopa kot edina ugledna in pomembna oseba med vsemi bosanskimi vstajniki (Ivić 1918: 47). Prizadevno gojenje tradicij »srbske vstaje v Bosni 1875-1878 « se je začelo s proslavo 50-letnice vstaje, ko so zahodno Bosno razglasili za »Krajino Petra Mrkonjića», Varcar Vakuf pa preimonovali v Mrkonjić Grad. Kralju Petru so leta 1924 odkrili spomenik v Dobrinju in v Nevesinju (Teinović 2006: 5). V zvezi s tem je bila ustvarjena tudi nova zgodba, dokaz nadčloveške predanosti kralja Petra Velikega boju za osvoboditev naroda, njegove požrtvovalnosti, ljubezni do domovine in osebnega poguma. Za stalno razstavo v Muzeju Vrbaske banovine v Banja Luki je tedanji direktor muzeja in slikar Špiro Bocarić naslikal več figuralnih kompozicij, med katerimi izstopa dostojanstveni lik vstajniškega vodje Petra Mrkonjića. Z leti so se ti dokazi vztrajno množili in postajali vse prepričljivejši. Da zgodba ne bi izgubila dramatičnosti, pa so skrbeli antijunaki v podobi agentov vlade kneza Milana, ki so menda v Mrkonjićevi četi sprožali nerede in upore, da bi mu »uničili ugled« ali ga celo odstranili s sveta (Ivić 1918: 35, 51; Petrović 1924: 14-15; Mrkonjić 1983: 51-52, 58-59).

Zgodovinarji v prvi skupni državi Jugoslovanov niso raziskovali vzrokov za nastanek in razvoj nacionalizmov, temveč so iskali zasluge za njeno ustanovitev. V tem prizadevanju je bil rezultat vnaprej znan. V skladu z veljavnim načelom političnega življenja so zgodovinske zasluge za osvoboditev in združitev pripisovali dinastiji Karađorđevićev. Da bi lik in delo bodočega kralja Petra prikazali v karseda svetli luči, so Hubmajerja, njegovega tekmeca za položaj glavnega poveljnika vstajniških čet na jamniški skupščini, upodabljali v ustrezno temnejših barvah. Nekdanji član Mlade Bosne in zgodovinar Vaso Čubrilović je v tem duhu zapisal, da je polom januarskega pohoda dokaz, »kako gre, kadar resne stvari vodijo neresni ljudje«. ${ }^{71}$ Hubmajer naj bi bil »zaigral« glavno poveljstvo v bosanski vstaji s svojim "noro pripravljenim in še bolj noro propadlim napadom na Kostajnico«, nato pa izginil iz bosanske vstaje prav tako hitro, kakor se je tudi pojavil. Oceno zaslug Crnega Miroslava je Čubrilović sklenil s posmrtno degradacijo: ko je Hubmajer nekaj mesecev pozneje kot prostovoljec vstopil v srbsko vojsko v vojni proti Osmanskem cesarstvu, mu je bil tam dodeljen »čin, ki mu je tudi povsem odgovarjal - naredniški« (Čubrilović 1930: 141).

Drugi pisci o vstajah v Hercegovini in Bosni so več let po Hubmajerjevem odhodu iz Bosne odkrili, da je kot prostovoljec v Bosni in Hercegovini zgolj pripravljal teren za avstro-ogrsko okupacijo obeh pokrajin (gl. npr. Krasić 1884: 86; Ivić 1918: 49-50; Karanović 1921: 41). Žal omenjeni avtorji niso pojasnili, kako je Hubmajer mogel nadaljevati svoje

70

Zastava, 3. (15.) 9. 1875: 4

71 Podobno oceno so v začetku septembra 1930 objavile tudi zagrebške Novosti: »Hubmayer je doživel poraz s Turki, bil je nesposoben, poleg tega pa se je ves ta posel s Hubmayerjem izkazal kot avstrijska diplomatska mahinacija» (Vojevanje Petra Mrkonjića u Bosni; Novosti, 6. 9. 1930: 6). 
delovanje z vključitvijo v srbsko artilerijo med srbsko-turško vojno 1876-1877 ${ }^{72}$ in pozneje še v Kresenski vstaji v Pirinski Makedoniji 1878-1879 (Luković 1977: 202).

Še korak dlje od Čubrilovića je naredil avtor poznane Istorije Jugoslavije. V obsežnem delu je Vladimir Ćorović posvetil pozornost tudi bosanski vstaji, pri čemer je našel nekaj prostora tudi za Miroslava Hubmajera, ki je skoraj pet let požrtvovalno in z velikim pogumom dajal sanjam o pomoči nesrečnim rojakom v njihovem boju proti zatiralcem prednost pred politično stvarnostjo. Presenetljivo, Ćorović je v Hubmajerju videl le lik - antijunaka. Po njegovih besedah je zaradi »razcepljenosti in zmedenosti« jamniška skupščina izbrala za glavnega četovodjo Hubmajerja, ne pa Mrkonjića. Zato je - namesto prave osebnosti - izbrala človeka »brez vsakršnih večjih sposobnosti«. Po Ćoroviću Hubmajer ni bil le »neprimeren za mesto, ki mu je bilo zaupano", ampak je končal življenje »kot avstrijska zaupna osebnost v Sarajevu“ (Ćorović 1933: 527). Pisec zgodovine prve skupne države Jugoslovanov je kot primerno metodo uporabil branje preteklosti nazaj, dogodke in osebnosti iz preteklosti, ki se niso dobro skladali z njegovo podobo, pa je po vzoru graditeljev skadarskega gradu vzidal v temelje svoje zgradbe. Najbrž na osnovi prepričanja, da bodo človeške žrtve, čeprav samo simbolične, okrepile stabilnost in trajnost Jugoslavije in njene vladajoče dinastije. ${ }^{73}$

Toda, če je bilo iskanje zgodovinskih zaslug za nastanek skupne države Jugoslovanov in njihovo pripisovanje za to primernim osebnostim razlog za potlačitev Miroslava Hubmajerja v temo pozabe, se odpira novo vprašanje - namreč vprašanje, zakaj je v drugi polovici 19. stoletja v svetu najbolj poznani Slovenec danes v svoji domovini še vedno pozabljen?

\section{REFERENCE}

Aleksić, Budimir. 2016. Knjaz Nikola Petrović i hercegovački ustanak (1875-1878). V: Draga Mastilović (ur.), Corovićevi susreti 2015. godine. Hercegovački ustanak 1875-1878. Gacko: SPKD »Prosvjeta«, 233-248.

Aléšovec, Jakob. 1878. Vojska na Turškem od leta 1875 do konca leta 1878. V Ljubljani: Založil Janez Giontini.

Besarović, Risto. 1947. Vaso Pelagić. Zagreb: Prosvjeta.

Besarović, Risto. 1951. Vaso Pelagić. Sarajevo: Svjetlost.

Besarović, Risto. 1969. Vaso Pelagić: Život i rad. Sarajevo: Izdavačko preduzeće Svjetlost.

Biankini, Juraj. 1925. »Narodni List« i hercegovačko-bosanski ustanak. Split: Narodna tiskarna.

Buha, Milivoje. 2003. Nevesinjska puška i hercegovački ustanak 1875-1878. godine. Srpsko Sarajevo: Zavod za udžbenike i nastavna sredstva.

72 Iz Srbskega. Slovenski Narod, 24. 10. 1876: 3; Krasić 1884: 89; Miroslav Hubmayer †. Slovenski Narod, 4. 3. 1910: 1; Čubrilović 1930: 141).

73 Da žrtev ni bila samo simbolična, izvemo iz pisma Hubmajerjeve hčerke Olge, v katerem je zapisala, da so Hubmajerjevi vdovi takoj po osvoboditvi ukinili pokojnino, ki jo je dobila pod avstro-ogrsko vlado. Brez sredstev za življenje njegova družina ni mogla niti označiti njegovega groba (Olga Hubmajer, Žalostno pismo. Orjuna, 8. 5. 1926: 1). 
Čubrilović, Vaso. 1930. Bosanski ustanak 1875-1878. Beograd: Izdanje Zadužbine Natalije Lj. Karavelove i Aksentija J. Aksentijevića.

Ćorović, Vladimir. 1933. Istorija Jugoslavije. Beograd: Narodno Delo.

De Worms, Baron Henry. 1877. England's Policy in the East. London: Chapman and Hall.

Dimnik, Jakob. 1922. Kralj Peter I. Osvoboditelj: Spominu Velikega Kralja Osvoboditelja - Ujedinitelja. Ljubljana: Društvo za zgradbo učiteljskega konvikta.

Durham, Mary Edith. 1920. Twenty Years of Balkan Tangle. London: George Allen \& Unwin.

Ekmečić, Milorad. 1973. Ustanak u Bosni 1875-1878. Sarajevo: „Veselin Masleša“.

Evans, Arthur John. 1877. Through Bosnia and Herzegovina during the Insurrection in 1875 by Foot. London: Longmans, Green, and Co.

Evans, Arthur John. 1878. Illyrian Letters. London: Longman, Green, and Co.

Freeman, Edward. 1877. The Ottoman Power in Europe. London: Macmillan \& Co.

Gallenga, Antonio. 1877. Two Years of the Eastern Question. London: Samuel Tinsley.

Gjurgjević, Martin. 1910. Memoari sa Balkana (1858-1878.). Sarajevo: Naklada samoga pisca.

Grujić, Kosta. 1956. Dnevnik iz hercegovačkog ustanka (od 6 avgusta do 16 oktobra 1875 godine). Beograd: Vojni muzej Jugoslovenske narodne armije.

Holeček, Josef. 1878. Za svobodu: Kresby z bojů černohorských a hercegovských proti Turküm. I. Praga: Nákladem vlastním.

Ivić, Aleksa. 1918. Fragmenti iz istorije bosanskog ustanka 1875. i 1876. g. Zagreb: Štampa Dioničke tiskare.

Jovanović, Radoman. 1977. Politički odnosi Crne Gore i Srbije 1860-1878. Cetinje: Obod.

Kapidžić, Hamdija. 1953. »Zastava« o Bosni i Hercegovini. Sarajevo: Svjetlost.

Karanović, Milan. 1921. Četovanje Vojvode Petra Mrkonjića - Kralja Petra - po Bosanskoj Krajini 1875.-76.: Po pričanju njegovog četnika-posilnog. Sarajevo: Štamparija Petra N. Gakovića.

Kermavner, Dušan. 1966. Slovenska politika v letih 1879 do 1895: Političnozgodovinske opombe k peti knjig Ivana Prijatelja Slovenske kulturnopolitične in slovstvene zgodovine 1848-1895. Ljubljana: Državna založba Slovenije.

Koetschet, Josef. 1905. Aus Bosniens Letzter Türkenzeit. Dunaj in Leipzig: A. Hartleben’s Verlag.

Kos, Angelika. 2006. Mihajlo Ljubibratić - vođa hercegovačkog ustanka. V: Dušan Berić (ur.), Nevesinjska puska:Zbornik radova sa naučnog skupa o ustanku u Hercegovini 1875-1878. Istočno Sarajevo: Zavod za udžbenike i nastavna sredstva, 55-78.

Krasić, Vladimir. 1884. Ustanak u Bosni od 1875. do 1878. god.: Grada za noviju srpsku istoriju rata za oslobodenje. U Novom Sadu: Štamparija A. Pajevića.

Ljubibratić, S. in T. Kruševac. 1958. Prilozi proučavaju Hercegovačkog ustanka 1875-78. godine. Godišnjak Istorijskog društva Bosne i Hercegovine 9: 257-276.

Luković, Petko. 1962. Napadi ustanika na turske karaule u donjoj Hercegovini 1875-1876. godine. Beograd.

Luković, Petko. 1977. Stališče Slovencev do vstaje v Hercegovini in Bosni in do bosansko-hercegovskega vprašanja $v$ letih 1875-1878. Ljubljana: Slovenska akademija zanosti in umetnosti.

Mackenzie, Georgina Muir in Adeline Paulina Irby. 1877. Travels in Slavonic Provinces of Turkey-in-Europe. London: Daldy, Isbister \& Co.

Mandić, Mihovil. 1910. Povijest okupacije Bosne i Hercegovine (1878). Zagreb: Izdanje »Matice hrvatske«. 
Milojković-Djurić, Jelena. 1994. Panslavism and National Identity in Russia and in the Balkans 1830-1880: Images of the Self and the Others. Boulder: East European Monographs.

Milutinović, Kosta. 1953. Vaso Pelagić i bosansko-hercegovački ustanak. Sarajevo: Seljačka knjiga.

Mrkonjić, Petar (Petar A. Karađorđević). 1983. Dnevnizapiscijednog ustaša o bosansko-hercegovačkom ustanku 1875-1876. godine. Beograd: Novinsko izdavačka radna organizacija »Tribina«.

Novak, Grga. 1925. Italija prema stvaranju Jugoslavije. Zagreb: Hrv. štamparski zavod.

Pajević, Arsa. 1891. Iz Crne Gore i Hercegovine: Uspomene vojevanja za narodno oslobodenje 1876. Novi Sad: Izdanje i štampa A. Pajevića.

Pavlović, Stevan K. 2004. Srbija: Istorija iza imena. Beograd: Clio.

Pavlowitch, Stevan K. 1999. A History of the Balkans 1804-1945. London in New York: Longman.

Pelagić, Vasa. 1880. Istorija bosansko-hercegovačke bune u svezi sa srpsko- i rusko-turskim ratom: (Študija za narod i državnike). Budimpešta: Štamparija Viktora Hornjanskoga.

Petrović Njegoš, Nikola I. 1988. Autobiografija. Memoari. Putopisi. Cetinje: Obod; Titograd: Pobjeda.

Petrović, P. M. 1924. Kralj Petar od rodenja do smrti. Beograd: Narodno delo.

Prelog, Milan. B. n. l. Povijest Bosne u doba osmanlijske vlade: II. Dio (1739-1878.). Sarajevo: Naklada J. Studničke i Druga.

Radonić, Jovan. 1938. Slike iz istorije i književnosti. Beograd: Državna štamparija Kraljevine Jugoslavije.

Rüffner, Eduard. 1877. Válka slovansko-turecká: S hledištè strategickébo a historického. Praga: Nákladem Aloise Hynka.

Rüstow, Wilhelm. 1877. Der Krieg in der Türkei: Zustände und Ereignisse auf der Balkanhalbinsel in den Jahren 1875 und 1876. Zürich: Druck und Verlag von F. Schultheß.

Seton-Watson, Robert William. 1931. The Role of Bosnia in International Politics (1875-1914). London: Humprey Milford.

Slipičević, Fuad idr. 1952. Bune i ustanci u Bosni i Hercegovini u XIX veku. Beograd: Vojnoistoriski institut JNA.

Stillman, William James. 1901. The Autobiography of a Journalist. London: Grant Richards.

Stillman, William James. 1932. Hercegovina iposlednji ustanak: Uzroci njegovi i sredstva. Beograd: Štamparija $\gg$ Privrednik «.

Stojanović, Mihailo D. 1939. The Great Powers and the Balkans 1875-1878. Cambridge: At the University Press.

Suavi, Ali. 1875. A propos de l'Herzegovine. Paris.

Teinović, Bratislav. 2006. Srpski ustanak u Bosni 1875-1878. Banja Luka: Muzej Republike Srpske.

Vego, Marko. 1953. Don Ivan Musić i Hrvati u hercegovačkom ustanku 1875-1878 godine. Sarajevo: Državna štamparija.

Vošnjak, Josip. 1912. Južnoslovanski spomini. Veda 1: 52-59.

Vukčević, Milo. 1950. Crna Gora i Hercegovina uoči rata 1874-1876. Cetinje: Narodna knjiga.

Vukićević, Milenko R. 1922. Kralj Petar od rodjenja do smrti. Beograd: Narodno delo.

Vuković, Gavro. 1925. Hercegovački i Vasojevićki Ustanak 1875 i 1876 g. Sarajevo: Štamparija »Bosanske Pošte«.

Wertheimer, Eduard von. 1910-1913. Graf Julius Andrássy: Sein Leben und seine Ziet. Nach ungedruckten Quellen. Stuttgart: Deutsche Verlagsanstalt. 
Yriarte, Charles. 1981 (1876). Bosna i Hercegovina - putopis iz vremena ustanka 1875-1876. Sarajevo: »Veselin Masleša «.

Zimmermann, Moritz B. 1878. Illustrierte Geschichte des Orientalischen Krieges von 1876-1878. Dunaj, Pešta in Leipzig: A. Harleben's Verlag.

\section{THE MOST RENOWNED SLOVENIAN HERO OF HIS TIME, FORGOTTEN} TODAY

The Nevesinje Uprising (SCr. Nevesinjska puška, literally 'Nevesinje Rifle') marked the beginning of the armed insurgency in Herzegovina on July 9th, 1875. From the town of Nevesinje it spread like wildfire across all of Herzegovina, although without a central leadership. Herzegovinians, whose pastoral life regularly took them into the uplands with their herds, knew where to find refuge and how to survive with little. During the insurgency, they used their upland refuges against Ottoman forces, Muslim villages, and caravans of merchants. Within a few weeks, they successfully isolated garrisons in Herzegovina, destroyed some lines of communications, and devastated and plundered some "Turkish" villages. About a month later, the insurrection spread to Bosnia, where it was limited to the Orthodox population, whereas Catholics took part in Herzegovina.

Starting as a peasant revolt, the Herzegovinian insurgency developed into a historical event of seismic importance. It opened the Eastern Question and attracted huge interest among European journalists, politicians, and the public, and especially the Slavic population in neighboring countries followed the developments with keen interest. For them, their Slavic "brothers" suffering under "Turkish" oppression were clearly on the right side of history. In order to support their efforts, they put together many committees in Croatia, Dalmatia, Slavonia, Serbia, and Montenegro, as well as in Slovenian lands. Those committees collected money, food, medicine, and weaponry, and even sent volunteers to fight on the side of insurgents.

One of the first to responded to this Slavic cause was Friedrich Hubmayer, a young Slovenian nationalist from Ljubljana. In Herzegovina he changed his "German" name into the Slovenian form Miroslav Hubmajer. He became famous as the insurgent leader Crni Miro 'Miro the Black'. Due to his fearlessness, he enjoyed great respect and soon became one of the most prominent faces of the insurgency. In the 1870s, his fame went much further than any of his Slovenian contemporaries. Newspapers regularly reported about him and his deeds. The Viennese newspaper Humoristische Blätter published his portrait on 10 October 1875, a work by the renowned Czech painter Karel Klić, and in its 1875 Christmas issue The Illustrated London News published a work on him featuring an illustration by the war reporter and special artist Melton Prior. 
However, when Hubmajer was elected the main leader of the Bosnian insurgency on December 16th-17th, 1875 at the assembly of representatives of all Bosnian insurgent groups, he stood in the way of Petar Mrkonjic (a pseudonym of Peter Karadordevic'), who was later proclaimed king of Serbia. Many intrigues were woven by the followers of Petar Mrkonjic against Hubmajer. After the establishment of the first Yugoslav nation-state, with King Peter I at its head, Hubmajer fell out of favor with historians as well. Despite his great reputation in the second half of the nineteenth century, Hubmajer is almost completely forgotten today.

Prof. Dr. Božidar Jezernik

University Ljubljana, Faculty of Arts, Department of Ethnology and Cultural Anthropology

Zavetiška 5, SI-1000 Ljubljana, bozidar.jezernik@ff.uni-lj.si 